Jurnal Ilmu Sosial dan Pendidikan (JISIP)

Vol. 6, No. 1 Januari 2022

e-ISSN : 2656-6753, p-ISSN: 2598-9944

DOI: 10.36312/jisip.v6i1.2784/http://ejournal.mandalanursa.org/index.php/JISIP/index

\title{
Kebijakan Dividen Sebagai Pemoderasi Dan Pengaruhnya Terhadap Likuiditas, Leverage Dan Profitabilitas Pada Nilai Perusahaan (Kasus Perusahaan Manufaktur Yang Terdaftar Di Bursa Efek Indonesia (BEI) Tahun 2017-2019)
}

\author{
Parida $^{1}$, Ni Ketut Surasni ${ }^{2}$, Baiq Nurul Suryawati ${ }^{3 *}$, Siti Aisyah Hidayati ${ }^{4}$ \\ ${ }^{1}$ Mahasiswa pada FEB Universitas Mataram, NTB, Indonesia \\ ${ }^{2,3,4}$ Dosen FEB Universitas Mataram, NTB, Indonesia
}

\begin{tabular}{l} 
Article Info \\
\hline Article history: \\
Received 31 Desember 2021 \\
Publish 04 Januari 2022
\end{tabular}

\section{Info Artikel}

Article history:

Received 31 Desember 2021

Publish 04 Januari 2022
Corresponding Author:

Baiq Nurul Suryawati

FEB Universitas Mataram

Email: nurul.suryawati@unram.ac.id

\begin{abstract}
This study aims to determine the effect of liquidity, leverage and profitability to the firm value with dividend policy as moderating variables in Manufacturing company listed on the Indonesia Stock Exchange (IDX) in 2017-2019.

This type of research is associative quantitative research. The data collection method used is Sample Survey method. The population in this study are all manufacturing companies listed on Indonesia Stock Exchange (IDX) of 182 companies. Sampling method with purposive sampling. And based on the criteria of the number of samples as many as 66 out of 182 companies. data analysis using multiple regression analysis with Moderated Regression Analysis (MRA).

The results showed that: Liquidity significant positive effect on firm value. Leverage significant positive effect on firm value. Profitability significant positive effect on firm value. Dividend policy is able to strengthen the effect of liquidity on the firm value. Dividend policy weakens the effect of leverage on the firm value. Dividend policy is not able to strengthen the effect of profitability on the firm value. ABSTRAK

Penelitian ini bertujuan untuk mengetahui pengaruh likuidtas, leverage dan profitabilitas terhadap nilai perusahaan dengan kebijakan dividen sebagai variabel moderasi pada perusahaan Manufaktur yang terdaftar di Bursa Efek Indonesia (BEI) tahun 2017-2019.

Jenis penelitian ini yaitu penelitian kuantitatif asosiatif. Metode pengumpulan data yang digunakan yaitu metode Sampel Survey. Populasi dalam penelitian ini adalah seluruh perusahaan manufaktur yang terdaftar diBursa Efek Indonesia (BEI) sejumlah 182 perusahaan. Metode pengambilan sampel dengan purposive sampling. Dan berdasarkan kriteria jumlah sampel sebanyak 66 dari 182 perusahaan. analisis data menggunakan analisis regresi berganda dengan Moderated Regression Analysis (MRA).

Hasil penelitian ini menunjukkan bahwa: Likuiditas berpengaruh positif signifikan terhadap nilai perusahaan. Leverage berpengaruh positif signifikan terhadap nilai perusahaan. Profitabilitas berpengaruh positif signifikan terhadap nilai perusahaan. Kebijakan dividen tidak mampu memperkuat pengaruh likuditas terhadap nilai perusahaan. Kebijakan dividen memperlemah pengaruh leverage terhadap nilai perusahaan. Kebijakan dividen tidak mampu memperkuat pengaruh profitabilitas terhadap nilai perusahaan.
\end{abstract}

This is an open access article under the Lisensi Creative Commons AtribusiBerbagiSerupa 4.0 Internasional

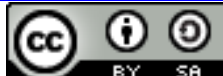




\section{PENDAHULUAN}

Berdirinya suatu perusahaan mempunyai tujuan. Ada tiga tujuan dalam mendirikan perusahaan. Tujuan pertama adalah mendapatkan keuntungan terbaik. Tujuan kedua, memakmurkan pemilik atau pemegang saham perusahaan, Tujuan ketiga perusahaan adalah memaksimalkan nilai perusahaan yang tercermin dari harga sahamnya. Tiga tujuan perusahaan tersebut tidak jauh berbeda. Hanya saja setiap perusahaan ingin mencapai prioritas yang berbeda (Artini, Suarjaya, \& Alfredo, 2012). Bagi pemegang saham dan calon investor nilai perusahaandapat memberikan informasi dan cerminan. Tingginya nilai perusahaan menunjukkantingkat kesejahteraan pemegangsaham atau pemilik perusahaan.

Menurut Fama (1978), "nilaiperusahaan akan tercermin dari harga sahamnya". Nilai pasar perusahaan adalah harga sahamyang terbentuk pada saat terjadinya transaksi. Investor akan percaya perusahaan tersebut mempunyai prospek yang baik dimasa yang akan datang pada saat nilai perusahaan itu tinggi. Pengukuran nilai perusahaan dapat dilihat melalui harga saham di pasar dalam kaitannya denganpermintaan dan penawaran harga jual beli sekurias (surat berharga) di pasar modal antara penjual maupun investor. Dengan demikian tingginya hargasaham membuat nilai perusahaan tinggi, nilai perusahaanyang tinggi dapat dilihat dari kinerja perusahaan yang baik. Sebelum melakukan investasi seorang investor harus mempertimbangkan banyak hal terkait informasi yang diperoleh dan menggunakannya sebagai dasar pengambilan keputusan investasi yaitu tentang kinerja perusahaan, kinerja perusahaan dapat dilihat pada laporan keuangan perusahaan (termasuk rasio keuangan). Rasio keuangan tersebut meliputi rasio likuiditas, leverage dan profitabilitas(Artini, Suarjaya, \& Alfredo, 2012).

Likuiditas menggambarkan kemampuan perusahaan dalam memenuhi kewajibannya yang harus dipenuhi pada saat penagihan. Jika perusahaan tersebut mampu menyelesaikan utang jangka pendeknya, maka perusahaan dapat dikatakan memiliki kinerja yang bagus. Semakin tinggi tingkat likuiditas yang dimiliki suatu perusahaan maka kinerja perusahaan semakin baik. Oleh karena itu, investor percaya bahwa perusahaan tersebut dapat meningkatkan nilai perusahaannya dan akan berdampak terhadap kemampuan perusahaan dalam membagikan dividen kepada pemegang saham. Dalam penelitian ini likuiditas diwakili oleh current ratio (CR), yaitu rasio yang menggambarkan kemampuan perusahaan dalam melunasi utang jangka pendeknya. Hasil penelitian Jariah (2016) menemukan hasil likuiditas berpengaruh signifikan terhadap nilai perusahaan. Tetapi berbeda dengan hasil penelitian yang dilakukan oleh Putri \& Ukhriwa (2016) menemukan bahwa likuiditas tidak berpengaruh terhadap nilai perusahaan. Dan dalam penelitian Mery (2017) menunjukkan hasil bahwa pengaruh likuiditas terhadap nilai perusahaan mampu dimoderasi oleh kebijakan dividen. Namun, hasil tersebut berbeda dengan penelitian Anggraeni \& Sulhan (2020) menunjukkan hasil bahwa pengaruh likuiditas terhadap nilai perusahaan tidak mampu dimoderasi oleh kebijakan dividen.

Leverage merupakanrasio yang menunjukkan bagaimana suatu perusahaan dapat mengelola utangnya untuk menghasilkan keuntungan dan melunasi utangnya. Perusahaan yang tidak dapat diselesaikan adalah perusahaan yang total utangnya lebih besar dari total" asetnya (Fahmi, 2014). Peningkatan penggunaan utang yang diumumkan oleh perusahaan berdampak positif pada harga saham yang akan dinilai membawa keuntungan positif bagi investor, dan akan mempengaruhi persepsi investor terhadap perusahaan dan mempengaruhi kenaikan harga saham dan berdampak pada nilai perusahaan yang tinggi. Ketika prospek masa depan suatuu perusahaan bagus, maka perusahaan tersebut dalam membayarkan apa yang menjadi hak pemegang saham dalam bentuk dividen dapat terpenuhi. Sehingga dalam hal ini perusahaan dapat mengelola hutangnya dan mampu melunasi hutangnya. Leverage dalam penelitian diwakili oleh Debt to Equity Ratio (DER), merupakan perbandingan antara utang dan modal perusahaan. Hasil penelitian Jariah (2016) menemukan hasil bahwa leverage memiliki pengaruh yang signifikan terhadap nilai perusahaan. 
Namun, berbeda dengan penelitian Prasetyorini (2013) menghasilkan bahwa leverage tidakberpengaruh terhadap nilai perusahaan. Dan dalam penelitian Rahmawati (2017) menemukan hasil bahwa pengaruh leverage terhadapnilai perusahaan mampu secara signifikan dimoderasi oleh kebijakan dividen. Namun, hasil tersebut berbeda dengan hasil penelitian Mery (2017) menunjukkan bahwa pengaruh leverage terhadap nilai perusahaantidak mampu secara signifikan dimoderasi olehkebijakan dividen.

Profitabilitas merupakan kemampuan suatu perusahaan untuk dalam menghasilkan keuntungan. Semakin besar keuntungan suatu perusahaan yang diperoleh dariaset, maka prospek perusahaan dalam menghasilkan keuntungan juga semakin besar, karena para investor memiliki dorongan untuk menginvestasikan modalnya pada perusahaan yang menghasiilkan keuntungan yang besar. Dengan demikian, tingkat pengembaliannya tinggi, dan juga akan mempengaruhi tingkat permintaan saham suatu perusahaan, serta tingginya nilai perusahhaan juga dipengaruhi. Profitabilitas dalam penelitian inidiwakili oleh Return on Equity (ROE), yaitu rasio yang menunjukkan kemampuan suatu perusahaan dalam menghasilkan keuntungan. Oleh karena itu, semakin tinggi tingkat profitabilitasmaka nilai perusahaan juga tinggi dan kemampuan perusahaan dalam membayarkan dividen kepada para pemegang saham terpenuhi. Hasil penelitian yang dilakukan oleh Putra \& Lestari (2016) menyatakan bahwa profitabilitas berpengaruh positif dan signifikan terhadap nilai perusahaan. Namun, berbeda dengan hasil penelitian Jariah (2016) menghasilkan bahwa profitabilitas tidak berpengaruh terhadap nilai perusahaan. Dan dalam penelitian yang dilakukan oleh Ihsan dkk (2018) menunjukkan hasil bahwa kebijakan dividen mampu secara signifikan memoderasi pengaruh profitabilitas terhadap nilai perusahaan. Namun, hasil tersebut berbeda dengan penelitian yang dilakukan oleh Sisca (2016) menunjukkan hasil bahwa kebijakan dividen tidak mampu memoderasi pengaruh profitabilitas terhadap nilai perusahaan.

Besarnya dividen yang dibayarkan kepada pemegang saham tergantung pada kebijakan dividen perusahaan dan didasarkan pada berbagai faktor. Menurut Gitman (2003) dalam Jariah (2016), faktor-faktor yang mempengaruhi kebijakan dividen perusahaan antara lain debt covenant, likuiditas, posisi kas, prospek pertumbuhan perusahaan, dan kuasa kendali pemegang saham perusahaan. Menurut Harjito \& Martono (2011:270), kebijakan dividen adalah untuk menentukan apakah laba yang dihasilkan pada akhir tahundibagikan dalam bentuk dividen kepada pemegang saham atau ditahan guna untuk menambah modal untuk pembiayaan di masa yang akan datang. Dalam penelitian ini kebijakan dividen diproksikan dengan Dividen Payout Ratio (DPR) sebagai pemoderasi likuiditas, leverage dan profitabilitas terhadap nilai perusahaan, karena keputusan kebijakan dividen adalah keputusan tentang menginvestasikan kembali keuntungan yang dimiliki saat ini sebagai dividen daripada menahannya di perusahaan (Brigham \& Houston, 2001). Dalam penelitian ini kebijakan dividen digunakan sebagai variabel moderasi, atau variabel yang meningkatkan atau memperlemah pengaruh likuiditas, leverage, dan profitabilitas terhadap nilai perusahaan. Karena pihak baik itu investor, kreditor, bahkan dari pihak lain yang berkepentingan seringkali menjadikan kebijakan dividen menjadi pusat perhatian, karena dividen memiliki informasi tentang bagaimana prospek perusahaan dimasa depan (Kartika, 2005) dalam (Alfredo, 2011). Dengan demikian, jika pemegang saham menerima apa yang menjadi haknya dalam bentuk dividen yang dibayarkan tinggi maka kinerja perusahaan semakin meningkat.

Peningkatan dividen per saham perusahaan dapat dipandang oleh investor sebagai perusahaan yang percaya diri dengan status keuangan perusahaan (Atmaja, 2001:6). Dalam Signaling theory perusahaan dapat terlihat berbeda ketika informasi yang diberikan bagus dibandingkan dengan perusahaan yang memiliki informasiyang tidak bagus. Dimana sinyal tersebut dapat dilihat dari tingkat likuiditas, leverage dan profitabilitas suatu perusahaan karena menunjukkan bagusnya kinerja perusahaan di masa depan. Oleh karena itu likuiditas, leverage dan profitabilitas merupakan sinyal bagi para investor untuk menentukan keputusan investasinya dan mengetahui prospek 
perusahaan di masa mendatang. Berikut data empiris Currrent Ratio (CR), Return on Equity (ROE), Debt to Equity Ratio (DER), Price to Book Value (PBV) dan Dividen Payout Ratio (DPR) pada beberapa perusahaan manufaktur yangmenjadi sampel penelitianyang terdaftar di Bursa Efek Indonesi (BEI) tahun 2017-2019.

Tabel 1. Rata-rata Currrent Ratio, Debt to Equity Ratio, Return on Equity, Price to Book Valuedan Dividen Payout Ratio pada beberapa perusahaan manufaktur yang menjadi sampel penelitianyang terdaftar di Bursa Efek Indonesi (BEI) tahun 2017-2019.

\begin{tabular}{|l|c|c|c|}
\hline \multirow{2}{*}{\multicolumn{1}{|c|}{ RATA-RATA }} & \multicolumn{3}{c|}{ TAHUN } \\
\cline { 2 - 4 } & 2017 & 2018 & 2019 \\
\hline Current Ratio (CR) (\%) & 297,48 & 287,83 & 322,33 \\
\hline Debt to Equity Ratio (DER) (\%) & 90,81 & 86,77 & 90,33 \\
\hline Return On Equity (ROE) (\%) & 17,31 & 20,07 & 15,33 \\
\hline Price to Book Value (PBV) (X) & 5,41 & 4,82 & 4,56 \\
\hline Dividen Payout Ratio (DPR) (\%) & 56,06 & 68,10 & 48,85 \\
\hline
\end{tabular}

Berdasarkan tabel diatas, dapat dilihat bahwa nilai rata-rata CR pada tahun 2017 sampai 2019 mengalami fluktuasi. Pada tahun 2018 CR mengalami penurunan dari 297,48 persen menjadi 287,83 persen, sedangkan pada tahun 2019 CR meningkat menjadi 322,33 persen. Hal yang sama juga terlihat pada rata-rata DER dimana pada tahun 2017 ke 2018 mengalami penurunan sedangkan pada tahun 2019 mengalami peningkatan. Pada rata-rata nilai ROE juga terjadi fluktuasi dimana pada tahun 2018 ROE mengalami peningkatan dari 17,31 persen menjadi 20,07 persen. Namun, pada tahun 2019 ROE mengalami penurunan menjadi 15,33 persen. Pada rata-rata nilai PBV dimana pada tahun 2017 sampai 2019, PBV cenderung menurun dari 5,41 kali pada tahun 2017 menjadi 4,56 kali pada tahun 2019. Berbeda dengan rata-rata DPR, dimana pada tahun 2018 DPR meningkat dari 56,06 persen menjadi 68,10 persen. Namun, pada tahun 2019 DER menurun menjadi 48,85 persen. Oleh karena itu, dapat dikatakan bahwa nilai rata-rata CR, DER dan ROE, tidak sejalan dengan nilai PBV perusahaan. Fenomena terjadinya fluktuasi dari rata-rata nilai CR, DER dan ROE tersebut menunjukkan bahwa kinerja perusahaan manufaktur pada tahun 2017 sampai 2019 dalam mengelola modalnya untuk membayar kewajiban serta menghasilkan laba masih belum stabil. Penurunan CR, DER dan ROE menggambar kinerja perusahaan yang tidak baik. Di mata investor, kinerja perusahaan merupakan salah satu faktor yang mempengaruhi fluktuasi harga saham dan mempengaruhi nilai perusahaan serta pembayaran deviden. Artinya, bahwa rata-rata perusahaan manufaktur di Indonesia tidak dapat secara efektif dalam memanfaatkan modal yang dimilikinya. Penelitian yang dilakukan oleh beberapa peneliti menunjukkan hasil yang tidak konsisten dan menimbulkan adanya research gapdari peneliti satu dengan yang lain. Oleh karena itu, penelitian ini ditujukan untuk menguji kembali kebijakan dividen sebagai pemoderasi dan pengaruhnya terhadap likuiditas, leverage dan profitabilitas pada nilai perusahaan di perusahaan manufaktur

\section{KAJIAN TEORI}

\subsection{Teori Sinyal (Signaliling Theory)}

Menurut Brigham dan Houston (2011) "Signal adalah kegiatan yang dilakukan oleh manajemen untuk memberikan arahan kepada seorang investor tentang bagaimana manajemen menilai prospek perusahaan”. Sinyal tersebut berbentuk informasi yang telah dilaksanakan oleh manajemen untuk mencapai kemauan pemiliknya. Informasi yang disampaikan oleh perusahaan sangat penting karena dapat mempengaruhi pihak luar. Informasi ini sangat diperlukan bagi investor untuk memahami prospek perusahaan dan bagaimana pengaruhnya terhadap perusahaan (baik di masa lalu, sekarang atau masa depan). 
Teori sinyal menunjukkan pentingnya informasi tentang keputusan investasi yang dikeluarkan oleh perusahaan. Informasi merupakan unsur penting bagi investor dan pebisnis, karena memberikan catatan dan deskripsi masa lalu, sekarang dan masa depan untuk perusahaan dan pasar modal. Sebelum mengambil keputusan investasi, Investor membutuhkan informasi (informasi yang relevan, akurat dan tepat waktu). Informasi yang diumumkanoleh perusahaan merupakan sinyal yangdigunakan untuk mengambil keputusan investasi oleh investor. Jika informasi yang diumumkan memiliki nilai yang positif, maka diharapkan pasar bereaksi saat pengumuman tersebut diterima pasar. Setelah informasi diumumkan dan pelaku pasar menerima informasi tersebut, maka terlebih dahulu pelaku pasar menganalisis dan mengartikan informasi tersebut sebagai sinyal yang baik atau buruk. Jika informasi tersebut merupakan sinyal yang baik bagi investor, maka akan terjadi perubahan terhadap volume perdagangan saham (Jogiyanto, 2013:392).

Berdasarkan uraian di atas, dapat disimpulkan bahwa teori sinyal adalah teori yang memberikan informasi tentang prospek masa depan perusahaan kepada investor. Jika sinyal tersebut memberikan informasi yang baik maka volume perdagangan saham akan berubah, sehingga investor pada umumnya akan lebih tertarik untuk berinvestasi pada perusahaan dengan sinyal yang baik. Namun, jika sinyal tersebut mengandung informasi yang buruk, investor tidak akan berinvestasi di perusahaan tersebut. Oleh karena itu teori tersebut sangat mempengaruhi keputusan investasi investor.

\subsection{Teori Asymmetric Informasi}

Menurut Sartono (2010), manajer biasanya tidak mengetahui banyak tentang pasar saham dan tingkat suku bunga di masa depan. Tetapi biasanya mereka mengetahui lebih banyak tentang status dan prospek perusahaan. Jika manajer memahami 10 prospek perusahaan lebih baik daripada analis investor, maka informasi asimetris akan muncul. Asimetri informasi merupakan asumsi bahwa manajer memiliki prospek perusahaan yang lebih baik daripada investor.

\subsection{Agency Theory (Teori Keagenan)}

Menurut Brigham \& Houston (2010:13-14), "teori keagenan merupakan hubungan dimana para manajer diberikan kekuasaan oleh para pemilik saham". Teori keagenan dilandasi oleh tiga asumsi, yaitu:

a. Asumsi tentang sifat manusia, bahwa manusia memiliki tiga sifat yaitu self interest, bounded rationality dan risk aversion atau sifat untuk mementingkan diri sendiri, memiliki keterbatasan rasionalitas, tidak menyukai risiko.

b. Asumsi tentang keorganisasian, yaitu komplik antar anggota organisasi, efisiensi sebagai kriteria produktifitas, dan adanya asimetri informasi antara principaldan agen.

c. Asumsi mengenai informasi adalah bahwa informasi diperlakukan sebagai komoditas yang dapat diperjualbelikan. Oleh karena itu, akses informasi membutuhkan pengorbanan. Manajer manajemen perusahaan biasanya menekankan pada pentingnya nilai tambah bagi perusahaan.

Menurut Nasser (2008:71) mengemukakan bahwa "pemisahan antara pemegang saham dan manajer seperti ini dapat menimbulkan adanya masalah keagenan atau agency theory. Dan karena kewenangan pengelolaan perusahaan serta pengambilan keputusan diserahkan kepada manajer, maka bisa saja manajer tidak berbuat yang terbaik untuk pemilik karena adanya perbedaan kepentingan".

\subsection{Teori Struktur Modal}

\section{Model Modigliani-Miller Tanpa Pajak}

Menurut Brigham \& Houston (2012:179), "teori struktur modal modern yang pertama adalah teori MM (Modigliani dan Miller). Mereka berpendapatbahwa struktur modal tidak 
relevan atau tidak mempengaruhi nilai perusahaan”.Modigliani dan Miller menyajikan beberapa asumsi untuk membagun teori mereka, yaitu:

a. Tidak ada biaya pialang

b. Tidak ada pajak

c. Biaya kebangkrutan tidak ada

d. Investor dapat meminjam dengan tingkat yang sama seperti perusahaan.

e. Informasi yang sama dimiliki oleh investor tentang peluang investasi di masa yang akan datang sama seperti manajemen.

f. Penggunaan hutang tidak mempengaruhi ebit.

Berdasarkan asumsi-asumsi tersebut,terdapat dua proposisi yang diajukan oleh Modigliani-Miller (MM) dan disebut sebagai proposisi Modigliani-Miller tanpa pajak.

Proposisi I: nilai perusahaan yang menggunakan hutang setara dengan nilai perusahaan yang tidak menggunakan hutang. Implikasi dari proposisi I ini adalah struktur modal darisuatu perusahaan tidak relevan, perubahan struktur modal tidakmempengaruhi nilai perusahaan dan Weighted Average Cost ofCapital (WACC) perusahaan akan tetap sama, tidak dapat mendukung bagaimana perusahaan menggabungkanhutang dan modal untukmembiayai perusahaan.

Proposisi II: Biaya modal saham akan meningkat jika perusahaan melakukan atau mencari pinjaman dari pihak luar. Risiko ekuitas tergantung pada risiko operasi perusahaan (risiko bisnis) dan tingkat utang perusahaan (risiko keuangan).

\section{Model Modigliani-Miller dengan Pajak}

Menurut Syahyunan (2013:221), Teori Modigliani-Miller tanpa pajak dianggap tidak realistis dan kemudian Modigliani-Miller memasukkan faktor pajak ke dalam teorinya. Pajak dibayarkan kepada pemerintah, yang berarti arus kas keluar. Hutang dapat digunakan untuk menghemat pajak, karena bunga dapat digunakan sebagai pengurang pajak.Terdapat dua proposisi dalam teori Modigliani-Miller dengan pajak yaitu:

a. Proposisi I: nilai perusahaan yang menggunakan hutang sama dengan nilai perusahaan yang tidak menggunakan hutang ditambah dengan penghematan pajak akibat bunga hutang. Implikasi dari proposisi I ini adalah pembiayaan hutang sangat menguntungkan dan Modigliani-Miller menyatakan bahwa struktur modal perusahaan yang optimal adalah hutang seratus persen.

b. Proposisi II: biaya modal saham akan meningkat dengan meningkatnya hutang, tetapi penghematan pajak akan lebih besar daripada penurunan nilai karena kenaikan biaya modal saham. Implikasi dari proposisi II adalah bahwa penggunaan hutang semakin meningkatkan biaya modal saham. Menggunakan lebih banyak hutang berarti menggunakan modal yang lebih murah (biaya modal hutang lebih kecil dari biaya modal saham), sehingga mengurangi biaya modal rata-rata tertimbang (walaupun biaya modal saham meningkat).

Teori Modigliani-Miller kontroversial, maksud dari teori ini adalah perusahaan harus menggunakan hutang sebanyak-banyaknya. Padahal pada kenyataannya, perusahaan yang memiliki hutang sebesar itu tidak ada, karena kemungkinan tingginya tingkat kebangkrutan dilihat dari tingkat hutang yang tinggi. Perusahaan harus menggunakan hutang sebanyak mungkin ialah alasan dibalik teori Modigliani-Miller, karena teori Modigliani-Miller mengabaikan biaya kebangkrutan.

\section{Nilai Perusahaan}

Nilai perusahaan adalah harga yang bersedia dibayar oleh calon pembeli saat perusahaan tersebut dijual. Untuk meningkatkan nilai perusahaan, manajemen telah mengadopsi berbagai kebijakan dengan meningkatkan kesejahteraan pemegang saham yang terlihat dari harga saham suatu perusahaan. Nilai perusahaan yang tinggi membuat pasar percaya terhadap prospek perusahaan yang dianggap penting bagi perusahaan, karena memaksimalkan nilai 
perusahaan berarti memaksimalkan kemakmuran pemegang saham yang merupakan tujuan utama perusahaan (Brigham \& Houston, 2001). Terdapat beberapa faktor yang mempengaruhi nilai perusahaan (Brigham \& Houston, 2012) yaitu:

a. Rasio likuiditas. Aset likuid adalah aset yang diperjualbelikan di pasar aktif (active market)yang mudah berubah dengan cepat menjadi uang tunai. Rasio likuiditas merupakan hubungan antara kas dan aset lancar lainnya dari perusahaan yang memiliki kewajiban lancar, jika perusahaan dapat melunasi hutangnya saat hutang tersebut jatuh tempo maka dikatakan perusahaan tersebut likuid.

b. Rasio Manajemen Aset. Rasio manajemen aset merupakan rasio yang menunjukkan jumlah aset yang terlihat normal dari sisi penjualan.

c. Rasio manajemen utang (leverage). Rasio leverage merupakan perbandingan antara dana perusahaan yang disimpan dengan jumlah pinjaman kreditur untuk mengukur tingkat pembiayaan usahanya.

d. Rasio profitabilitas. Rasio profitabilitas merupakan kemampuan perusahaan dalam menghasilkan laba, kekayaan bersih perusahaan dan modal sendiri.

Sedangkan menurut Sudana (2015), faktor yang mempengaruhi nilai perusahaan, yaitu:

a. Keputusan investasi. Keputusan investasi adalah keputusan investasi jangka panjang yang melibatkan ekspektasi perusahaan akan keuntungan masa depan. Keputusan investasi berkaitan dengan proses satu atau lebih alternatif investasi, yang dianggap mendapatkan keuntungan dari berbagai alternatif investasi yang tersedia bagi perusahaan.

b. Keputusan pendanaan (struktur modal). Dalam pengambilan keputusan, manajer keuangan harus mempertimbangkan dan menganalisis sumber modal ekonomi perusahaan agar dapat menyediakan dana untuk kebutuhan investasi dan kegiatan bisnis perusahaan.

c. Kebijakan dividen. Kebijakan dividen merupakan bagian bagian dari keputusan pembelanjaan perusahaan, khususnya berkaitan dengan pembelanjaan internal perusahaan. Kebijakan dividen merupakan kebijakan manajemen keuangan yang menentukan:

1) Besarnya prosentase laba yang akan dibagikan kepada para pemegang saham salam bentuk cash dividen.

2) Stabilitas dividen yang dibagikan.

3) Dividen saham (Stock dividen).

4) Pemecahan saham (Stock split).

5) Penarikan Kembali saham yang beredar yang semuanya ditunjukkan untuk meningkatkan kemakmuran para pemegang saham.

Perusahaan mempertimbangkan faktor-faktor ini untuk mencapai tujuannya dalam memaksimalkan nilai perusahaan. Yang dapat diukur sesuai dengan pembentukan harga sahamyang mencerminkan penilaian publik terhadap kinerja keuangan perusahaan yang sebenarnya perusahaan di pasar (Harmono, 2014). Jenis pengukuran nilai perusahaan menurut Fahmi (2015) adalah sebagai berikut:

a. Earing Per Share (EPS). Laba per saham atau biasa dikenal dengan earning per share (EPS) merupakan suatu bentuk keuntungan bagi pemegang saham dari setiap kepemilikan saham.

b. Price Earning Ratio (PER). Price Earning Ratio adalah perbandingan antara harga pasar perlembar saham dengan laba per lembar saham. Semakin tinggiprice earning ratio maka pertumbuhan laba yang diharapkan juga mengalami kenaikan.

c. Price Book Value (PBV). Price Book Value menggambarkan seberapa besar pasar menghargai nilai buku saham perusahaan.

Sedangkan menurut Brigham \& Daves (2014) dalam rasio penilaian perusahaan terdiri dari:

a. Price Earning Ratio (PER), menurut Tandelilin (2010), Price Earning Ratio (PER) merupakan perbandingan antara harga saham perusahaan dengan laba bersih per saham 
(EPS) perusahaan. PER adalah fungsi dari perubahan kapabilitas laba masa depan yang diharapkan. Semakin tinggi rasio harga-pendapatan, semakin besar kemungkinan perusahaan akan tumbuh, yang dapat meningkatkan nilai perusahaan.

b. Tobin's $Q$, menurut Weston \& Copeland (2001), metode alternatif lain yang dikembangkan oleh Jamin Tobinyang digunakan untuk mengukur nilai perusahaan yaitu metode Tobin Q yang merupakan perbandingan antara rasio nilai pasar saham perusahaan dengan nilai buku perusahaan. Tobin's Q adalah nilai pasar aset perusahaan dengan biaya penggantian. Dalam konsep ini, rasio Q lebih baik daripada rasio nilai pasar terhadap nilai buku karena berfokus pada nilai perusahaan dari pada biaya saat ini. Pada pelaksanaannya, Rasio Q sulit dihitung secara akurat karena tidak mudah memperkirakan biaya penggantian aset perusahaan (Margaretha, 2014:20)

c. Price Book Value (PBV). Rasio ini mengukur nilai yang diberikan pasar keuangan kepada manajemen dan organisasi perusahaan sebagai sebuah perusahaan yang terus tumbuh (Brigham \& Houston, 2006). PBV menjelaskan seberapa besar pasar mengapresiasi nilai buku saham perusahaan juga menunjukkan sejauh mana perusahaan mampu menciptakan nilai perusahaan relatif terhadap jumlah modal yang diinvestasikan. Tingginya nilai PBV membuat pasar percaya terhadap prospek masa depan perusahaan. Selain itu, PBV juga menunjukkan apakah harga saham yang diperdagangkan overvalued (di atas) atau undervalued (di bawah) nilai buku saham tersebut.

Nilai perusahaan dalam penelitian ini diwakili oleh Price Book Value (PBV). Karena banyak digunakan dalam keputusan investasi, rasio ini mengukur nilai yang diberikan pasar keuangan kepada manajemen dan organisasi perusahaan untuk pertumbuhan perusahaan (Brigham \& Houston, 2006). PBV menggambarkan sejauh mana pasar menghargai nilai buku saham perusahaan. Semakin tinggi rasionya, pasar meyakini prospek masa depan perusahaan. PBV juga menunjukkan sejauh mana perusahaan dapat menciptakan nilai perusahaan relatif terhadap jumlah modal yang diinvestasikan. Selain itu, PBV juga menunjukkan apakah harga saham perdagangan overvalued (di atas) atau undervalued (di bawah).

\section{Kebijakan dividen}

Menurut Sudana (2015), kebijakan dividen merupakan bagian dari keputusan pembelajaran yang berkaitan dengan pembelajaran internal perusahaan. Kebijakan dividen merupakan kebijakan keuangan yang digunakan untuk melihat besaran persentase profit yang akan dibagikan dalam bentuk dividen tunai kepada pemegang saham guna untuk peningkatan kesejahteraan pemegang saham (Gitusudarmo \& Basri, 2002).

Faktor tersebut diatas adalah factor yang harus dipertimbangkan untuk memaksimalkan nilai perusahaan. Kebijakan dividen diwakili olehDividen Payout Ratio (DPR) yang merupakan perbandingan antara dividen yang dibayarkan dengan laba bersih yang didapatkan(Gitusudarmo \& Basri, 2002), Dividen Payout Ratio (DPR) dapat dirumuskan sebagai berikut:

$$
\text { Dividen Payout Ratio(DPR) }=\frac{\text { Total Dividen }}{\text { Laba Bersih }}
$$

Berdasarkan uraian di atas, disimpulkan bahwa kebijakan dividen merupakan kebijakan keuangan yang menentukan persentase keuntungan yang dibagikan kepada pemegang saham dalam bentuk dividen tunai, stabilitas pembagian dividen, dividen saham (stock divident), pemecahan saham dan penarikan saham yang beredar dan ditujukan untuk meningkatkan kesejahteraan pemegang saham.

Menurut preferensi investor ada tiga teori yang mendasari kebijakan (Brigham \& Houston, 2011:211), yaitu:

a. Teoti ketidakrelevan Dividen. Teori dividen tidak relevan merupakan teori dari Merton Miller dan Franco Modiglami (MM). Teori ini mengatakan bahwa harga saham dan biaya modal tidak dipengaruhi oleh kebijakan dividen.Selain itu, teori MM juga berpendapat 
bahwa besar kecilnya dividen payout ratiotidak mempengaruhi nilai perusahaan. Tetapi, hanya dipengaruhi oleh profitabilitas dasar dan risiko usahanya dengan syarat bahwa dividen yang dibayarkan tidak dikenakan pajak penghasilan. Seluruh informasi yang dimiliki oleh manajer maupun pemegang saham mengenai laba perusahaan dimasa medatang adalah sama.

b. Teori "bird in the hand". Teori ini mengatakan pembagian dividen yang tinggi merupakan cara untuk memaksimalkan nilai perusahaan. Hal tersebut merupakan pandangan dari Merton dan Franco Modiglian (MM).

c. Teori preferensi pajak. Terdapat tiga alasan yang berhubungan dengan pajak dan berpendapat bahwapembagian dividen yang rendah mungkin lebih disukai oleh investor dari pada yang tinggi, yaitu:

1) Dibandingkan dengan tarif pajak penghasilan investasi, tarif pajak penghasilan dividen lebih tinggi, yang meningkatkan kemungkinan perusahaan menahan dan menginvestasikan kembali keuntungan investor dengan kekayaan bersih tinggi yang memiliki saham paling banyak dan menerima dividen paling banyak. Dipercaya bahwa keuntungan yang lebih tinggi akan menyebabkan harga saham yang lebih tinggi, dan keuntungan modal kena pajak yang lebih rendah akan menggantikan dividen yang lebih tinggi.

2) Karena pengaruh nilai dari waktu ke waktu, tidak ada pajak penghasilan yang dibayarkan sebelum saham dijual.

3) Jika saham tersebut dimiliki oleh seseorang sampai kematiannya, sama sekali tidak perlu membayar pajak capital gain. Ahli waris yang menerima saham dapat menggunakan nilai saham pada tanggal kematian sebagai dasar biaya, sehingga menghindari pajak capital gain.

\section{Penelitian Terdahulu}

Terdapat beberapa hasil penelitian terdahulu yang berkaitan dengan pengaruh likuiditas, leverage dan profitabilitas terhadap nilai perusahaan dengan kebijakan dividen sebagai variabel moderasi. Penelitian tersebut adalah sebagai berikut:

a. Anggraeni \& Sulhan (2020), dengan judul penelitian pengaruh profitabilitas, likuiditas dan leverage terhadap nilai perusahaan dengan kebijakan dividen sebagai variabel moderasi. Menggunakan analisis regresi linear berganda dan moderated regression. Dengan hasil penelitian menunjukkan bahwa hanya likuiditas tidak berpengaruh terhadap nilai perusahaan. dan hanya likuiditas yang tidak mampu secara signifikan dimoderasi oleh kebijakan dividen terhadap nilai perusahaan.

b. Ihsan, dkk (2018), dengan judul penelitian pengaruhlikuiditas, leverage dan profitabilitas, terhadap nilai perusahaan dengan kebijakan dividen sebagai variabel moderasi. Menggunakan analisis moderated regression. Dengan hasil penelitian menunjukkan bahwa likuiditas, leverage dan profitabilitas berpengaruh positif dan signifikan terhadap nilai perusahaan. hanya profitabilitas yang mampu secara signifikan dimoderasi oleh kebijakan dividen terhadap nilai perusahaan.

c. Jariah (2016), dengan judul penelitian pengaruhlikuiditas, leverage dan profitabilitas, terhadap nilai perusahaan. Menggunakan analisis linear berganda. Dengan hasil penelitian menunjukkan bahwa secara parsial hanya variabel profitabilitas yang berpengaruh dan signifikan terhadap nilai perusahaan. Secara simultan likuiditas, leverage dan profitabilitas berpengaruh terhadap nilai perusahaan dan kebijakan dividen. Secara parsial hanya leverage yang mempunyai hubungan yang cukup kuat dan tidak searah terhadap nilai perusahaan.Kebijakan dividen mempunyai hubungan yang tidak signifikan terhadap nilai perusahaan manufaktur di Indonesia. 
d. Sisca (2016), dengan judul penelitian pengaruh leverage dan profitabilitas terhadap nilai perusahaan dengan kebijakan dividen sebagai variabel moderasi pada perusahaan manufaktur yanng terdaftar di bursa efek Indonesia tahun 2010-2014 dengan menggunakan analisis berganda dan moderated analisis, dengan hasil penelitian secara simultan leverage, profitabilitas dan kebijakan dividen berpengaruh positif dan signifikan terhadap nilai perusahaan, sedangkan secara parsial hanya profitabilitas yang mempunyai pengaruh positif signifikan terhadaap nilai perusahaan. Dan kebijakan dividen tidak mampu secara signifikan memoderasi pengaruh leverage dan profitabilitas terhadap nilai perusahaan.

e. Putra \& Lestari (2016), dengan judul penelitian pengaruhkebijakan dividen, likuiditas, profitabilitas dan ukuran perusahaan terhadap nilai perusahaan. Menggunakan analisis regresi berganda. Dengan hasil penelitian menunjukkan bahwa Kebijakan dividen berpengaruh positif dan signifikan terhadap nilai perusahaan. Likuiditas, profitabilitas dan ukuran perusahaan berpengaruh positif dan signifikan terhadap nilai perusahaan.

f. Prasetyorini (2013), dengan judul penelitian pengaruhpengaruh ukuran perusahaan, leverage, price earning ratio dan profitabilitas terhadap nilai perusahaan. Menggunakan analisis regresi berganda. Dengan hasil penelitian menunjukkan bahwa variabel ukuran perusahaan, price earning ratio, dan profitabilitas berpengaruh terhadap nilai perusahaan. Variabel leverage tidak berpengaruh terhadap nilai perusahaan.

g. Putri \& Ukhriwati (2016), pengaruh likuiditas, leverage dan profitabilitas, terhadap nilai perusahaan. Menggunakan analisis regresi berganda. Dengan hasil penelitian menunjukkan bahwa variabel leverage dan profitabilitas secara parsial berpengaruh terhadap nilai perusahaan. Variabel likuiditas tidak berpengaruh terhadap nilai perusahaan. secara simultan variabel likuiditas, leverage dan profitabilitas berpengaruh terhadap nilai perusahaan.

h. Rahmawati (2017), pengaruhlikuiditas, leverage dan profitabilitas, terhadap nilai perusahaan dengan kebijakan dividen sebagai variabel moderasi. Menggunakan analisis regresi \& moderated regression. Dengan hasil penelitian menunjukkan bahwa hanya variabel profitabilitas berpengaruh terhadap nilai perusahaan. Kebijakan dividen mampu secara signifikan memoderasi pengaruh leverage, profitabilitas terhadap nilai perusahaan. Kebijakan dividen tidak mampu secara signifikan memoderasi pengaruh likuiditas terhadap nilai perusahaan.

i. Mery (2017), pengaruh likuiditas, leverage dan profitabilitas, terhadap nilai perusahaan dengan kebijakan dividen sebagai variabel moderasi. Menggunakan analisis regresi berganda. Dengan hasil penelitian menunjukkan bahwa variabel likuiditas dan profitabilitas berpengaruh terhadap nilai perusahaan. Leverage tidak berpengaruh terhadap nilai perusahaan. Kebijakan dividen tidak mampu secara signifikan memoderasi pengaruh leverage terhadap nilai perusahaan. Kebijakan dividen mampu secara signifikan memoderasi pengaruh likuiditas dan profitabilitas terhadap nilai perusahaan.

j. Prasetya (2020), dengan judul penelitian pengaruhlikuiditas, leverage dan profitabilitas, terhadap nilai perusahaan yang dimoderasi oleh kebijakan dividen. Menggunakan analisis moderated regression. Dengan hasil penelitian menunjukkan bahwa hanya profitabilitas berpengaruh positif dan signifikan terhadap nilai perusahaan,dan hanya profitabilitas yang mampu diperkuat hubungan pengaruhnya oleh kebijakan dividen terhadap nilai perusahaan.

k. Lestari (2015), dengan judul penelitian pengaruh likuiditas, leverage dan profitabilitas terhadap nilai perusahaan dengan kebijakan dividen sebagai variabel moderasi. Menggunakan analisis regresi moderasi dengan hasil penelitian likuiditas, leverage dan profitabilitas berpengaruh positif terhadap nilai perusahaan. Dan kebijakan dividen dapat memperkuat pengaruh likuiditas, leverage dan profitabilitas terhadap nilai perusahaan. 
Berdasarkan uraian diatas, yang menghasilkan variabel berpengaruh adalah hasil penelitian oleh Lestari (2015), Putra \& Lestari (2016). Sedangkan yang menghasilkan variabel yang tidak berpengaruh adalah penelitian dari Prasetya (2020), Mery (2017), Rahmawati (2017), Putri \& Ukhriwati (2016), Prasetyorini (2013), Sisca (2016), Jariah (2016), Ihsan, dkk (2018), Anggraeni \& Sulhan (2020).

\section{METODE PENELITIAN}

\subsection{Jenis Penelitian}

Jenis penelitian yang dilakukan dalam penelitian ini adalah kuantitatif asosiatif. Penelitian kuantitatif asosiatif bertujuan untuk mengetahui ada tidaknya pengaruh sebab dan akibat antara variabel dengan objek yang diteliti (Sugiyono, 2016). Penelitian ini bertujuan untuk mengetahui ada tidaknya pengaruh dari likuiditas, leverage dan profitabilitas terhadap nilai perusahaan dengan kebijakan dividen sebagai variabel moderasi pada perusahaan manufaktur yang terdaftar di Bursa Efek Indonesia (BEI) tahun 2017-2019.

\subsection{Lokasi dan Waktu Penelitian}

Lokasi Penelitian

Penelitian ini dilakukan pada perusahaan manufaktur yang terdaftar di Bursa Efek Indonesia (BEI). Penelitian ini dilakukan tidak mendatangi langsung perusahaan yang dijadikan sebagai objek penelitian. Namun, mengakses data melalui www.sahamoke.com dan www.idx.co.id.

\section{Waktu Penelitian}

Adapun waktu penelitian menggunakan periode 2017 sampai 2019 untuk perusahaan manufaktur yang terdaftar di Bursa Efek Indonesia (BEI).

\subsection{Metode Pengumpulan Data}

Dalam penelitian ini, metode pengumpulan data yang digunakan adalah metode sampel survey. Metode sampel survey yaitu metode dengan pengambilan data sampel dari populasi (Sugiyono, 2018:17). Digunakan metode sampel survey dalam penelitian ini karena data yang dikumpulkan berdasarkan sampel yang telah dipilih dari jumlah populasi yaitu sebanyak 182 perusahaan.

\subsection{Teknik Pengumpulan Data}

Menurut Sugiyono (2016:137), teknik pengumpulan data adalah "cara untuk memperoleh data dan keterangan yang mendukung penelitian ini". Teknik pengumpulan data dalam penelitian ini menggunakan teknik dokumentasi yaitu teknik yang digunakan untuk memperoleh data yang sudah ada pada objek penelitian. Sumber data yang digunakan adalah data sekunder berupa laporan keuangan tahunan yang dipublikasikan oleh perusahaan manufaktur yang terdaftar di Bursa Efek Indonesia (BEI) tahu 2017-2019. Menurut Sugiyono (2016:137), sumber sekunder adalah "sumber yang tidak langsung memberikan data kepada pengumpul data (lewat orang lain atau lewat dokumen)", untuk mendapatkan informasi berupa data laporan keuangan tahunan yang didapatkan melalui situs resmi Bursa Efek Indonesia (BEI) dan situs dan resmi dari perusahaan. Selain itu data yang didapat berupa informasi jumlah seluruh jumlah perusahaan manufaktur yang terdaftar di Bursa Efek Indonesia (BEI) tahun 2017-2019 diakses dari www.sahamoke.com.

\subsection{Populasi dan Sampel}

\section{Populasi}

Populasi adalah daerah generalisasi yang mempunyai kualitas dan karakteristik tertentu yang ditetapkan oleh peneliti untuk dipelajari dan kemudian ditarik kesimpulannya (Sugiyono, 2016:115). Populasi dalam penelitian ini adalah seluruh perusahaan manufaktur yang terdaftar di Bursa Efek Indonesia (BEI) tahun 2017-2019 yang berjumlah 182 perusahaan. 


\section{Sampel}

Sampel adalah bagian dari ukuran dan karakteristik populasi (Sugiyono, 2014:81). Teknik pengambilan sampel yang digunakan dalam penelitian ini adalah metode purposive sampling yaitu teknik penentuan sampel setelah mempertimbangkan faktor-faktor tertentu (Sugiyono, 2014:120). Tujuan pemilihan sampel menggunakan metode purposive sampling adalah untuk mendapatkan sampel yang sesuai dengan kriteria yang telah ditentukan, adapun kriteria sampel yang akan diteliti:

a. Perusahaan manufaktur yang terdaftar di Bursa Efek Indonesia (BEI) pada tahun 20172019.

b. Perusahaan manufaktur yang mempublikasikan laporan keuangan tahunan selama periode pengamatan dari tahun 2017-2019.

c. Perusahaan manufaktur yang membagikan dividen secara berturut-turut pada tahun 20172019.

Tabel 2. Kriteria Pengambilan Sampel

\begin{tabular}{|l|l|c|}
\hline No & \multicolumn{1}{|c|}{ Kriteria penelitian } & Jumlah \\
\hline 1. & $\begin{array}{l}\text { Perusahaan Manufaktur yang terdaftar di Bursa } \\
\text { Efek Indonesia (BEI) pada tahun 2017-2019 }\end{array}$ & 182 \\
\hline 2. & $\begin{array}{l}\text { Perusahaan yang tidak mempublikasikan laporkan } \\
\text { laporan keuangan tahunan secara berturut pada } \\
\text { tahun 2017-2019 }\end{array}$ & $(28)$ \\
\hline 3. & $\begin{array}{l}\text { Perusahaan yang tidak membagikan dividen secara } \\
\text { berturut-turut pada tahun 2017-2019 }\end{array}$ & $(88)$ \\
\hline & \multicolumn{1}{|c|}{ Total Sampel Penelitian } & $\mathbf{6 6}$ \\
\hline
\end{tabular}

Sehingga dengan adanya kriteria yang ditentukan, maka dalam penelitian ini menggunakan sampel sebanyak 66 perusahaan.

\subsection{Variabel Penelitian}

Klasifikasi Variabel

a. Variabel Independen $(\mathrm{X})$

Variabel independen merupakan variabel yang menjadi sebab atau yang mempengaruhi variabel dependen (Sugiyono, 2016). Variabel independen yang digunakan dalam penelitian ini adalah likuiditas (Current Ratio), leverage (Debt to Equity Ratio) dan profitabilitas (Return on Equity Ratio).

b. Variabel dependen (Y)

Variabel terikat atau variabel dependen adalah variabel yang dipengaruhi atau menjadi variabel bebas atau hasil dari variabel bebas (sugiyono, 2016:39). Variabel dependen yang digunakan dalam penelitian ini adalah nilai perusahaan yang diproksikan dengan Price Book Value (PBV).

c. Variabel moderasi (Z)

Variabel moderator adalah variabel yang dapat memperkuat atau memperlemah hubungan antara variabel dengan variabel lain (Sugiyono, 2012). Variabel moderasi yang digunakan dalam penelitian ini adalah kebijakan dividen yang diproksikan dengan Dividend Payout Ratio (DPR).

\subsection{Definisi Konseptual dan Operasional Variabel}

Tabel 3. Konseptual dan Operasional Variabel

\begin{tabular}{|l|l|l|l|}
\hline Variabel & Konseptual Variabel & Operasional Variabel & Satuan \\
\hline Dependen
\end{tabular}




\begin{tabular}{|c|c|c|c|}
\hline $\begin{array}{l}\text { Nilai } \\
\text { Perusahaan } \\
\text { (PBV) }\end{array}$ & $\begin{array}{l}\text { Untuk mengukur nilai suatu } \\
\text { perusahaan, penelitian ini } \\
\text { menggunakan metode Price } \\
\text { Book Value (PBV), yang } \\
\text { menunjukkan apakah harga } \\
\text { saham yang diperdagangkan } \\
\text { tersebut overvalued (diatas) } \\
\text { atau undervalued (dibawah). }\end{array}$ & $\begin{array}{l}\text { Data diolah menggunakan excel } \\
\text { dimana data yang didapat dari } \\
\text { laporan keuangan perusahaan } \\
\text { yang menjadi sampel penelitian. }\end{array}$ & Ratio \\
\hline \multicolumn{4}{|l|}{ Independen } \\
\hline $\begin{array}{l}\text { Likuiditas } \\
\text { (CR) }\end{array}$ & $\begin{array}{l}\text { Current Ratio (CR) adalah } \\
\text { ukuran yang umum digunakan } \\
\text { untuk solvabilitas jangka } \\
\text { pendek, yaitu kemampuan suatu } \\
\text { perusahaan untuk memenuhi } \\
\text { kebutuhan hutang pada saat } \\
\text { jatuh tempo. }\end{array}$ & $\begin{array}{l}\qquad C R=\frac{\text { Aset Lancar }}{\text { Utang Lancar }} \\
\text { Data diolah menggunakan excel } \\
\text { dimana data yang didapat dari } \\
\text { laporan keuangan perusahaan } \\
\text { yang menjadi sampel penelitian. }\end{array}$ & Ratio \\
\hline $\begin{array}{l}\text { Leverage } \\
\text { (DER) }\end{array}$ & $\begin{array}{l}\text { Debt to equity ratio (DER) } \\
\text { adalah ukuran yang digunakan } \\
\text { untuk menganalisis laporan } \\
\text { keuangan untuk menunjukkan } \\
\text { besarnya jaminan yang } \\
\text { diberikan kepada kreditur }\end{array}$ & $\begin{array}{l}\text { DER }=\frac{\text { Total Liabilities }}{\text { Total Modal Sendiri }} \\
\text { Data diolah menggunakan excel } \\
\text { dimana data yang didapat dari } \\
\text { laporan keuangan perusahaan } \\
\text { yang menjadi sampel penelitian. }\end{array}$ & Ratio \\
\hline $\begin{array}{l}\text { Profitabilita } \\
\text { s (ROE) }\end{array}$ & $\begin{array}{l}\text { Rasio Return on equity (ROE) } \\
\text { disebut juga dengan laba atas } \\
\text { equity. Rasio ini menguji sejauh } \\
\text { mana perusahaan menggunakan } \\
\text { sumber dayanya untuk } \\
\text { menyediakan ekuitas. }\end{array}$ & $\begin{array}{l}=\frac{\text { Earning After Tax }(E A T)}{\text { Modal Sendiri }} \\
\text { Data diolah menggunakan excel } \\
\text { dimana data yang didapat dari } \\
\text { laporan keuangan perusahaan } \\
\text { yang menjadi sampel penelitian. }\end{array}$ & Ratio \\
\hline \multicolumn{4}{|l|}{ Moderasi } \\
\hline \multirow{2}{*}{$\begin{array}{l}\text { Kebijakan } \\
\text { Dividen } \\
\text { (DPR) }\end{array}$} & \multirow{2}{*}{$\begin{array}{lr}\text { Suatu keputusan apakah laba } \\
\text { yang diperoleh } & \text { suatu } \\
\text { perusahaan akan di tahun untuk } \\
\text { diinvestasikan kembali atau } \\
\text { dibagikan sebagai dividen }\end{array}$} & $=\frac{\text { Total Dividen }}{\text { Laba Bersih }}$ & \multirow[t]{2}{*}{ Ratio } \\
\hline & & $\begin{array}{l}\text { Data diolah menggunakan excel } \\
\text { dimana data yang didapat dari } \\
\text { laporan keuangan perusahaan } \\
\text { yang menjadi sampel penelitian. }\end{array}$ & \\
\hline
\end{tabular}

\subsection{Prosedur Analisis Data}

Data yang telah dikumpulkan melalui analisis rasio keuangan seperti rasio likuiditas, leverage dan profitabilitas serta data dari nilaiperusahaan dan kebijakan dividen yang diperoleh dari laporan keuangan tahunan diolah menggunakan Microsoft excel kemudian diolah kembali menggunakan teknik analisis data. Dalam penelitian ini untuk menyelesaikan masalah teknik analisis data yang digunakan adalah uji statistik regresi berganda dengan Moderated Regression Analysis (MRA) yang digunakan untuk mengetahui dan memperoleh gambaran mengenai 
pengaruh likuiditas, leverage dan profitabilitas terhadap nilai perusahaan dengan kebijakan dividen sebagai variabel moderasi pada perusahaan manufaktur yang terdaftar di Bursa Efek Indonesia (BEI) tahun 2017-2019 dengan bantuan Statistical Package for the Sociaty Sciences (SPSS) 16.0 .

\subsection{Analisis Deskriptif Data}

Deskriptif data merupakan suatu gambaran data yang digunakan dalam suatu penelitan. Metode analisis berisi pengujian data yang didapatkan kemudian dianalisis.

\section{Analisis Statistik Deskriptif}

Analisis statistik deskriptif adalah metode pengorganisasian dan analisis data kuantitatif, dengan tujuan untuk memperoleh gambaran kegiatan yang teratur. Instrumen yang digunakan adalah mean, median, modus, maksimum, minimum dan standar deviasi (Sembiring, 2003).

\section{Uji Normalitas}

Uji normalitas digunakan untuk menguji normalitas data. Uji normalitas bertujuan untuk menguji apakah variabel dependen dan variabel independen mempunyai distribusi normal dalam metode regresi. Model regresi yang baik adalah data yang berdistribusi normal atau mendekati normal (Ghozali, 2013:147). Kolmogorov-Smirnov digunakan dalam penelitian ini. Apabila nilai Kolmogorov-Smirnov > 0,05 berarti data berdistribusi normal (Ghozali, 2012).

\section{Uji Asumsi Klasik}

Model regresi yang baik harus memiliki data dengan distribusi normal atau mendekati distribusi normal, dan tidak ada asumsi regresi. Pengujian hipotesis regresi dalam penelitian ini meliputi:

\section{Uji Multikolinieritas}

Uji multikolinearitas bertujuan untuk menguji apakah model regresi menemukan adanya korelasi antara variabel independen (Ghozali, 2011). Pada penelitian ini digunakan indikator variance inflation factor (VIF) untuk mengukur uji multikolinearitas. Jika nilai VIF lebih besar dari 10 maka akan terjadi multikolinieritas antar variabel independen.

\section{Uji Heteroskedastisitas}

Uji heteroskedastisitas merupakan uji yang digunakan untuk mengetahui apakah dalam model regresi terjadi ketidaksamaan dari residual satu pengamatan ke pengamatan lainnya (Ghozali, 2012). Model regresi dinyatakan sebagai alat prediksi yang tidak valid ketika uji heteroskedastisitas tidak terpenuhi. Dalam penelitian ini, untuk mendeteksi adanya gejala heteroskedastisitas akan digunakan uji Glejser. Jika satu variabel (independen) mempengaruhi variabel lain (independen) maka data akan mengalami heteroskedastisitas. Jika nilai signifikansi variabel independen lebih kecil dari 0,05 maka dikatakan terdapat masalah heteroskedastisitas. Begitu pula sebaliknya, jika nilai efektif variabel independen lebih besar dari 0,05 maka tidak terjadi masalah heteroskedastisitas.

\section{Uji Autokorelasi}

Uji autokorelasi bertujuan untuk menguji apakah model regresi linier memiliki korelasi antara kesalahan pengganggu (residual) periode $\mathrm{t}$ dan kesalahan periode $\mathrm{t}-1$ (Ghozali, 2012). Untuk mendeteksi adanya autokorelasi maka akan dilakukan uji Durbin-Watson (DW test). Asumsi adanya autokorelasi dalam pengambilan keputusan adalah jika bilangan D-W merepresentasikan D antara DU dan 4-DU, berarti tidak ada autokorelasi, dan D <DL atau D $>$ 4-DU menyatakan ada autokorelasi.

\subsection{Analisi Regresi}

Analisis regresi adalah teknik statistika yang digunakan untuk mencari persamaan regresi untuk memprediksi nilai variabel dependen berdasarkan nilai variabel independen, mencari kemungkinan kesalahan, dan menganalisis suatu variabel dengan dua atau lebih variabel independen secara parsial atau simultan. Hubungan antara. Regresi bertujuan untuk menguji hubungan antara satu variabel dengan variabel lainnya (Sugiyono, 2014). Analisis regresi yang 
digunakan dalam penelitian ini adalah analisis linear berganda dengan Moderated Regression Analysis (MRA).

Menurut Ghozali (2013) Moderated Regression Analysis (MRA) merupakan metode analisis yang menjaga integritas sampel dan memberikan dasar untuk mengendalikan pengaruh variabel moderator. Untuk menentukan jenis variabel moderasi ketiga persamaan regresi tersebut harus dibandingkan. Ketiga persamaan tersebut adalah (Ghozali, 2013: 219):

Untuk menguji $\mathrm{H} 1, \mathrm{H} 2$ dan $\mathrm{H} 3$ digunakan persamaan statistik sebagai berikut:

$\mathrm{Yi}=\alpha+\beta_{1} \mathrm{X}_{1}+\beta_{2} \mathrm{X}_{2}+\beta_{3} \mathrm{X}_{3}+\varepsilon$

Untuk melihat jenis moderasi digunakan persamaan sebagai berikut:

$\mathrm{Yi}=\alpha+\beta_{1} \mathrm{X}_{1}+\beta_{2} \mathrm{X}_{2}+\beta_{3} \mathrm{X}_{3}+\beta_{4} \mathrm{Z}+\varepsilon$

Jika hasil pengujian yang dilakukan menunjukkan bahwa variabel yang diamati merupakan variabel moderasi maka persamaan yang akan dianalisis untuk menguji H4, H5 dan H6 adalah sebagai berikut:

$$
\begin{array}{cl}
\mathrm{Y}=\alpha+\beta_{1} \mathrm{X}_{1}+ & \beta_{2} \mathrm{X}_{2}+\beta_{3} \mathrm{X}_{3}+\beta_{4} \mathrm{Z}+\beta_{5} \mathrm{X}_{1} \mathrm{Z}+\beta_{6} \mathrm{X}_{2} \mathrm{Z}+\beta_{7} \mathrm{X}_{3} \mathrm{Z}+\varepsilon \\
\text { Dimana: } & : \text { Variabel dependen (Nilai perusahaan / PBV) } \\
\mathrm{Y} & : \text { nilai konstanta } \\
\alpha & : \text { Varibel independen (CR,DER ROE) } \\
\mathrm{X} & : \text { nilai koefisien regresi } \\
\mathrm{Z} & : \text { Variabel moderasi (Kebijakan Dividen /DPR) } \\
\mathrm{e} & : \text { Error }
\end{array}
$$

Untuk menguji keberadaan variabel moderasi apakah benar sebagai pure moderator, quasi moderator, prediktor moderasi, atau moderasi potensial, dapat diamati dengat kriteria sebagai berikut (Satrianto, 2020):

a. Pure moderator merupakan variabel yang memoderasi hubungan antara variabel independen dengan dependen, dimana variabel pure moderator (moderasi muri) berintraksi dengan variabel independen tanpa menjadi variabel independen. Apabila pengaruh dari Z terhadap Y pada persamaan pertama tidak signifikan sedangkan intraksi $\mathrm{Z}^{*} \mathrm{X} 1$ pada persamaan kedua signifikan.

b. Quasi moderator merupakan variabel yang memoderasi hubungan antara variabel independen dan variabel dependen, dimana variabel moderasi semu berintraksi dengan variabel dependen sekaligus menjadi variabel independen. Apabila pengaruh dari Z terhadap $\mathrm{Y}$ pada persamaan pertama signifikan dan pengaruh intraksi $\mathrm{Z}^{*} \mathrm{X} 1$ pada persamaan kedua juga signifikan.

c. Prediktor moderasi, apabila pengaruh dari $\mathrm{Z}$ terhadap $\mathrm{Y}$ pada persamaan pertama signifikan sedangkan intraksi $\mathrm{Z}^{*} \mathrm{X} 1$ pada persamaan kedua tidak signifikan. Artinya variabel ini hanya berperan sebagai variabel independen dalam model hubungan yang dibentuk.

d. Potensial Moderasi, apabila pengaruh $\mathrm{Z}$ terhadap $\mathrm{Y}$ pada persamaan pertama dan pengaruh intraksi $Z^{*} \mathrm{X} 1$ pada persamaan kedua tidak ada satupun yang signifikan. Artinya, variabel ini tidak berintraksi dengan variabel independen dan juga tidak memiliki hubungan terhadap variabel dependen.

\subsection{Pengujian Hipotesis}

Hipotesis yaitu jawaban sementara yang diberikan hanya berdasarkan pada teori yang relevan dan belum didasarkan pada fakta yang diperoleh dari pengumpulan data (Sugiyono, 2012). Pengujian terhadap hipotesis yang dilakukan dalam penelitian ini dengan cara sebagai berikut:

\section{Uji Statistik t (Parsial)}

Secara parsial atau uji statistik t merupakan uji yang digunakan untuk melihat seberapa jauh pengaruh pengaruh variabel independen dengan variabel dependen. Menurut Ghozali 2130 | Kebijakan Dividen Sebagai Pemoderasi Dan Pengaruhnya Terhadap Likuiditas, Leverage Dan Profitabilitas Pada Nilai Perusahaan (Parida) 
(2013), uji t-statistik pada dasarnya menunjukkan besarnya pengaruh suatu variabel bebas dalam menjelaskan perubahan variabel terikat. Tingkat signifikansi untuk pengujian ini adalah $0,05(\alpha=5 \%)$. Terima atau tolak hipotesis dengan ketentuan sebagai berikut:

- Jika nilai signifikan > 0,05 maka hipotesis ditolak. Artinya secara parsial variabel independen tidak berpengaruh signifikan terhadap variabel dependen.

- Jika nilai signifikan $\leq 0,05$ maka hipotesis diterima. Artinya secara parsial variabel independen berpengaruh signifikan terhadap variabel dependen

Uji Intraksi / Moderated Regression Analysis (MRA)

Moderated Regression Analysis (MRA) merupakan aplikasi khusus regresi linear berganda yang didalamnya mengandung unsur interaksi yang dihasilkan dari perkalian dua atau lebih variabel independen (Ghozali, 2013:219). Pengambilan keputusan didasarkan pada pengaruh hubungan antara variabel independen dengan variabel dependen dapat dilihat dari taraf signiifikansinya yaitu 0,05 (Ghozali, 2013:211):

1) Jika nilai signifikan $>0,05$ maka hipotesis ditolak.

2) Jika nilai signifikan $\leq 0,05$ maka hipotesis diterima

Uji F (Uji kelayakan model)

Menurut Ghozali (2011), uji goodness of fit (uji kelayakan model) dilakukan untuk mengukur ketepatan fungsi regresi sampel dalam menaksirkan nilai aktual secara statistik. Model goodness of fit dapat diukur dari nilai statistik F yang menunjukkan apakah semua variabel independen yang dimasukkan dalam model mempunyai pengaruh secara bersamasama terhadap variabel dependen.

- Jika nilai signifikan >0,05, maka model regresi dinyatakan tidak layak atau tidak dapat digunakan untuk menjelaskan pengaruh variabel independen terhadap variabel dependen.

- Jika nilai signifikan $\leq 0,05$ maka model regresi dinyatakan layak atau dapat digunakan untuk menjelaskan pengaruh variabel independen terhadap variabel dependen.

\section{Uji $\boldsymbol{R}^{2}$ ( Koefisien Derterminasi)}

Menurut Ghozali (2011), koefisien determinasi diukur untuk mengetahui persentase pengaruh variabel independen terhadap perubahan variabel dependen. Nilai koefisien determinasi berada pada kisaran 0 sampai 1. Nilai yang lebih kecil menunjukkan bahwa variabel independen memiliki kemampuan yang sangat terbatas dalam menjelaskan perubahan variabel dependen, begitu pula sebaliknya.Koefisien determinasi dapat dihitung dengan menggunakan rumus sebagai berikut:

$\mathrm{Kd}=\mathrm{R}^{2}$ x $100 \%$

Keterangan:

$\mathrm{Kd} \quad$ : koefisien determinasi

$\mathrm{R}^{2} \quad$ : koefisien korelasi

a. Jika Kd mendeteksi nol (0), maka variabel independen memiliki pengaruh yang lemah terhadap variabel dependen.

b. Jika Kd mendeteksi satu (1), maka variabel independen memiliki pengaruh yang kuat terhadap variabel dependen.

\section{HASIL TEMUAN DAN PEMBAHASAN}

\subsection{Hasil Penelitian}

\section{Gambaran Umum Objek Penelitian}

Perusahaan manufaktur merupakan perusahaan industri pengolahan yang mengolah bahan baku menjadi barang setengah jadi atau barang jadi. Perusahaan manufaktur identik dengan pabrik yang mengaplikasikan mesin-mesin, peralatan, teknik rekayasa dan tenaga kerja. Perusahaan manufaktur (manufacturing) atau industri manufaktur di Indonesia yang sudah go 
publik di Bursa Efek Indonesia (BEI) dikelompokkan kedalam sektor dan sub sektor. Ada 3 sektor perusahaan manufaktur diantaranya sektor industri dasar dan kimia, sektor aneka industri dan sektor barang konsumsi.

\section{Deskripsi Data}

Dalam penelitian ini data yang digunakan adalah data sekunder berupa laporan keuangan tahunan seperti data likuiditas (CR), leverage (DER), profitabilitas (ROE), kebijakan dividen (DPR) dan nilai perusahaan (PBV). Uraian deskripsi data akan disajikan sebagai berikut:

\section{Analisis deskriptif}

Statistik deskriptif merupakan analisis yang memberikan suatu gambaran atau mendeskripsikan suatu data yang dapat dilihat dari nilai rata-rata (mean), standar deviasi, varian, maksimum, minimum (Sugiyono, 2016).

Tabel 4. Analisis Statistik Deskriptif

\begin{tabular}{|l|r|r|r|r|r|}
\hline & $\mathrm{N}$ & Minimum & Maximum & Mean & $\begin{array}{c}\text { Std. } \\
\text { Deviation }\end{array}$ \\
\hline Likuiditas(CR) & 198 & 24.06 & 2170.45 & $3.0255 \mathrm{E} 2$ & 258.86244 \\
Leverage (DER) & 198 & 9.06 & 435.44 & 89.3011 & 79.76905 \\
Profitabilitas (ROE) & 198 & .18 & 327.72 & 18.7320 & 33.81200 \\
Kebijakan Dividen & 198 & .56 & 1611.81 & 57.6741 & 126.14030 \\
(DPR) & & & & & \\
Nilai Perusahaan & 198 & .17 & 171.29 & 5.7782 & 15.00768 \\
(PBV) & 198 & & & & \\
Valid N (listwise) & & & & \\
\hline
\end{tabular}

Berdasarkan tabel diatas, dapat diketahui hasil sebagai berikut:

a. Nilai Perusahaan, berdasarkan tabel diatas, nilai perusahaan memiliki rata-rata sebesar 5.7782, nilai standar deviasi 15.00768, nilai maksimum sebesar 171.29 dan nilai minimum sebesar 0.17. Dari nilai minimum dan maximum menunjukkan bahwa tingkat Price Book Value (PBV) yang diperoleh antara 0.17 sampai 171.29 menunjukkan bahwa nilai perusahaan mengalami fluktuasi setiap tahunnya. Nilai rata-rata sebesar 5,7782 kali menunjukkan bahwa sejauh mana kemampuan perusahaan dapat menciptakan nilai perusahaan relatif terhadap jumlah modal yang diinvestasikan dengan standar deviasi sebesar 15.00768.Nilai maksimum sebesar 171.29 terjadi pada perusahaan Semen Indonesia Tbk (SMGR) tahun 2017, dan nilai minimum sebesar 0.17 terjadi pada perusahaan Ultra Jaya Milk Industry \& Trading Company Tbk (ULTJ) tahun 2019.

b. Likuiditas, berdasarkan tabel diatas, likuiditas memiliki rata-rata sebesar 3.0255, nilai standar deviasi 258.86244, nilai maksimum sebesar 2170.45 dan nilai minimum sebesar 24.06. Dari nilai minimum dan maximum menunjukkan bahwa tingkat Current Ratio (CR) yang diperoleh antara 24,06 sampai 2170.45 menunjukkan bahwa likuiditas berfluktuasi. Nilai rata-rata likuiditas sebesar 3.0255 persen menunjukkan bahwa kemampuan suatu perusahaan dalam memenuhi kebutuhan utang jangka pendek pada saat jatuh tempo dengan standar deviasi sebesar 258.86244. Nilai maksimum sebesar 2170.45 terjadi pada perusahaan Duta Pertiwi Nusantara Tbk (DPNS) tahun 2019, dan nilai minimum sebesar 24.06 terjadi pada perusahaan Indah Kiat Pulp dan Paper Tbk (INKP) tahun 2018.

c. Leverage, berdasarkan tabel diatas, leverage memiliki rata-rata sebesar 89.3011, nilai standar deviasi 79.76905, nilai maksimum sebesar 435.44 dan nilai minimum sebesar 9.06. Dari nilai minimum dan maximum menunjukkan bahwa tingkat Debt to Equity Ratio (DER) 
yang diperoleh antara 9.06 sampai 435.44 menunjukkan leverage berfluktuasi setiap tahunnya. Nilai rata-rata leverage sebesar 89,30 persen menunjukkan bahwa kemampuan perusahaan untuk memenuhi seluruh kewajiban jangka panjang dan jangka pendeknya dengan standar deviasi sebesar 79.76905. Nilai maksimum sebesar 435.44 terjadi pada perusahaan Indomobil Sukses Internasional Tbk (IMAS) tahun 2019, dan nilai minimum sebesar 9.06 terjadi pada perusahaan Industri Jamu dan Farmasi Sido Muncul Tbk (SIDO) tahun 2017.

d. Profitabilitas, berdasarkan tabel diatas, leverage memiliki rata-rata sebesar 18.7320, nilai standar deviasi 33.81200, nilai maksimum sebesar 327.72 dan nilai minimum sebesar 0.18. Dari nilai minimum dan maximum menunjukkan bahwa tingkat Return on Equity (ROE) yang diperoleh antara 0.18 sampai 327,72 menunjukkan bahwa profitabilitas berfluktuasi. Nilai rata-rata profitabilitas sebesar 18.73 persen menunjukkan kemampuan perusahaan untuk menghasilkan laba dengan standar deviasi sebesar 33.81200. Nilai maksimum sebesar 327.72 terjadi pada perusahaan Fajar Surya Wisesa Tbk (FASW) tahun 2018, dan nilai minimum sebesar 0.18 terjadi pada perusahaan Asahimas Flat Glass Tbk (AMFG) tahun 2018.

e. Kebijakan Dividen, berdasarkan tabel diatas, kebijakan dividen memiliki rata-rata sebesar 57.6741, nilai standar deviasi 126.14030, nilai maksimum sebesar 1611.81 dan nilai minimum sebesar 0.56. Dari nilai minimum dan maximum menunjukkan bahwa tingkat Dividend Payout Ratio (DPR) yang diperoleh antara 0.56 sampai 1611.81 hal ini menunjukkan bahwa kebijakan dividen juga berfluktuasi. Nilai rata-rata kebijakan dividen sebesar 57,67 persen menunjukkan bahwa kemampuan perusahaan untuk membayar dividen yang dibagikan kepada pemegang saham dengan standar deviasi sebesar 126.14030.Nilai maksimum sebesar 1611.81 terjadi pada perusahaan Merck Tbk (MERK) tahun 2018, dan nilai minimum sebesar 0.56 terjadi pada perusahaan Lion Metal Works Tbk (LION) tahun 2019.

\section{Uji Normalitas}

Uji normalitas digunakan untuk menguji normalitas data. Uji normalitas bertujuan untuk menguji apakah variabel dependen dan variabel independen mempunyai distribusi normal dalam metode regresi. Model regresi yang baik adalah data yang berdistribusi normal atau mendekti normal (Ghozali, 2013:147).

Tabel 5. Hasil Uji Normalitas

One-Sample Kolmogorov-Smirnov Test

\begin{tabular}{|ll|r|}
\hline & & $\begin{array}{r}\text { Unstandardiz } \\
\text { ed Residual }\end{array}$ \\
\hline $\mathrm{N}$ & & 198 \\
Normal Parameters ${ }^{\mathrm{a}}$ & Mean & .0000000 \\
& Std. Deviation & 1.05023776 \\
Most Extreme & Absolute & .077 \\
Differences & Positive & .077 \\
& Negative & -.038 \\
Kolmogorov-Smirnov Z & 1.081 \\
Asymp. Sig. (2-tailed) & .193 \\
\hline a. Test distribution is Normal. & \\
\hline
\end{tabular}


Dari tabel diatas diketahui bahwa nilai Asymp. Sig. (2-tailed) dari variabel penelitian yakni likuiditas, leverage, profitabilitas, nilai perusahaan dan kebijakan dividen sebesar 0,193. Karena nilai Asymp. Sig. (2-tailed) lebih besar dari 0,05 (0,193>0,05), maka dapat disimpulkan bahwa kelima dari data variabel penelitian berdistribusi normal.

\section{Uji Asumsi Klasik}

\section{a. Uji multikolineritas}

Uji multikolineritas bertujuan untuk menguji apakah model regresi menemukan adanya korelasi antara variabel independen (Ghozali, 2011). Model regresi yang baik yaitu apabila tidak terjadi korelasi antara variabel independen dan tidak terdapat multikolineritas. Indikator tolerance dan variance inflation factor (VIF) untuk mengukur uji multikolineritas. Jika nilai VIF adalah 10 dan tolerance value adalah 0,1 . Jika VIF lebih besar dari 10 dan tolerance lebih kecil dari 0,1. Maka akan terjadi multikolinieritas antar variabel independen.

Tabel 6. Hasil Uji multikolineritas

Tolerancedan Variance Inflation Factor (VIF)

Coefficients ${ }^{\mathbf{a}}$

\begin{tabular}{|c|c|c|c|c|c|c|c|c|}
\hline \multirow{2}{*}{\multicolumn{2}{|c|}{ Model }} & \multicolumn{2}{|c|}{$\begin{array}{c}\text { Unstandardized } \\
\text { Coefficients }\end{array}$} & \multirow{2}{*}{$\begin{array}{c}\text { Standardized } \\
\text { Coefficients } \\
\text { Beta }\end{array}$} & \multirow[b]{2}{*}{$\mathrm{t}$} & \multirow[b]{2}{*}{ Sig. } & \multicolumn{2}{|c|}{$\begin{array}{c}\text { Collinearity } \\
\text { Statistics }\end{array}$} \\
\hline & & B & Std. Error & & & & $\begin{array}{c}\text { Tolera } \\
\text { nce }\end{array}$ & VIF \\
\hline \multirow[t]{5}{*}{1} & (Constant) & -6.051 & 1.468 & & -4.122 & .000 & & \\
\hline & Likuiditas(CR) & .457 & .170 & .252 & 2.689 & .008 & .415 & 2.410 \\
\hline & Leverage (DER) & .451 & .132 & .321 & 3.428 & .001 & .415 & 2.408 \\
\hline & Profitabilitas (ROE) & .589 & .075 & .484 & 7.839 & .000 & .956 & 1.046 \\
\hline & $\begin{array}{l}\text { Kebijakan Dividen } \\
\text { (DPR) }\end{array}$ & .328 & .068 & .300 & 4.835 & .000 & .950 & 1.053 \\
\hline
\end{tabular}

a. Dependent Variable: Nilai Perusahaan (PBV)

Berdasarkan tabel diatas, hasil uji multikolineritas diketahui bahwa nilai tolerance variabel independen menunjukkan nilai signifikansi > 0,1, yaitu likuiditas sebesar 0.415 , Leverage sebesar 0.415, profitabilitas sebesar 0.956, dan kebijakan dividen sebesar 0.950 . Sedangkan nilai VIF variabel independen < 10, yaitu likuiditas sebesar 2.410,leverage sebesar 2.408, profitabilitas sebesar 1.046, dan kebijakan dividen sebesar 1.053 maka dapat disimpulkan bahwa tidak terjadi multikolineritas.

b. Uji Heteroskedastisitas

Uji heteroskedastisitas bertujuan untuk menguji apakah dalam model regresi terjadi ketidaksamaan variance dari residual satu ke pengamatan pengamatan yang lain (Ghozali, 2012). Jika asumsi heteroskedastisitas tidak terpenuhi, maka model regresi dinyatakan sebagai alat prediksi yang tidak valid. Dalam penelitian ini, untuk mendeteksi adanya gejala heteroskedastisitas akan digunakan uji Glejser. Dasar pengambiilan keputusan uji heteroskedastisitas Glejser adalah jika nilai signifikansi (Sig) antara variabel independen dengan absolut residual lebih besar dari 0,05, maka tidak terjadi masalah heteroskedastisitas. 
Tabel 7. Hasil Uji Heteroskedastisitas

Uji glejser

Coefficients $^{\mathrm{a}}$

\begin{tabular}{|c|c|c|c|c|c|c|}
\hline \multirow{2}{*}{\multicolumn{2}{|c|}{ Model }} & \multicolumn{2}{|c|}{$\begin{array}{l}\text { Unstandardized } \\
\text { Coefficients }\end{array}$} & \multirow{2}{*}{$\begin{array}{l}\text { Standardized } \\
\text { Coefficients } \\
\text { Beta } \\
\end{array}$} & \multirow[b]{2}{*}{$\mathrm{t}$} & \multirow[b]{2}{*}{ Sig. } \\
\hline & & B & Std. Error & & & \\
\hline 1 & (Constant) & 79.867 & 7.227 & & 11.051 & .000 \\
\hline & Likuiditas (CR) & -.003 & .003 & -2.925 & -.841 & .402 \\
\hline & Leverage (DER) & -.021 & .021 & -.939 & -.984 & .327 \\
\hline & Profitabilitas (ROE) & .011 & .066 & .609 & .168 & .867 \\
\hline & $\begin{array}{l}\text { Kebijakan Dividen } \\
\text { (DPR) }\end{array}$ & .011 & .025 & 2.549 & .425 & .671 \\
\hline
\end{tabular}

a. Dependent Variable: ABS_1

Berdasarkan tabel diatas, menunjukkan bahwa semua variabel independen memiliki nilai signifikansi > 0,05 yaitu, likuiditas sebesar 0,402, leverage sebesar 0,327, profitabilitas sebesar 0,867 dan kebijakan dividen sebesar 0,671, maka model regresi dapat dikatakan tidak terjadi heteroskedastisitas.

c. Uji autokorelasi

Uji autokorelasi bertujuan untuk menguji apakah model regresi linier memiliki korelasi antara kesalahan pengganggu (residual) periode $\mathrm{t}$ dan kesalahan periode $\mathrm{t}-1$ (Ghozali, 2011). Untuk mendeteksi adanya autokorelasi maka akan dilakukan uji DurbinWatson (DW test). Asumsi adanya autokorelasi dalam pengambilan keputusan dengan ketentuan sebagai berikut:

a. Jika DW < dL atau DW > 4-dL, maka terjadi Autokorelasi

b. Jika dU $<$ DW $<4$ - dU, maka tidak terjadi autokorelasi

c. Jika $\mathrm{dL}<\mathrm{DW}<\mathrm{dU}$ atau 4-dU $<\mathrm{DW}<4$ - dL, maka tidak ada kesimpulan

Tabel 8. Hasil Uji Autokorelasi

Durbin Watson (DW)

Model Summaryb

\begin{tabular}{|l|r|r|r|r|r|}
\hline Model & R & R Square & $\begin{array}{c}\text { Adjusted R } \\
\text { Square }\end{array}$ & $\begin{array}{l}\text { Std. Error of } \\
\text { the Estimate }\end{array}$ & $\begin{array}{l}\text { Durbin- } \\
\text { Watson }\end{array}$ \\
\hline 1 & $.544^{\mathrm{a}}$ & .296 & .282 & 1.06107 & 1.909 \\
\hline
\end{tabular}

a. Predictors: (Constant), Kebijakan Dividen (DPR), Likuiditas(CR),

Profitabilitas (ROE), Leverage (DER)

b. Dependent Variable: Nilai Perusahaan (PBV)

Dari tabel diatas diketahui bahwa nilai Durbin-Watson (DW test) dari variabel penelitian yakni likuiditas, Leverage, profitabilitas, nilai perusahaan dan kebijakan dividen sebesar 1,909. Dimana hasil uji autokorelasi Durbin-Watson (DW test) sebagai berikut:

$$
\begin{aligned}
& \mathrm{N}=198 \\
& \mathrm{DW}=1,909 \\
& \mathrm{dL}=1,7263 \\
& \mathrm{dU}=1,8087
\end{aligned}
$$


$4-\mathrm{dL}=4-1,7263=2,2737$

$4-\mathrm{dU}=4-1,8087=2,1913$

Jika dU < DW < 4- dU, maka tidak terjadi autokorelasi atau 1,8087 < 1,909 <

2,1913, dengan demikian dapat disimpulkan bahwa tidak ada autokorelasi

\section{Analisis Regresi}

Analisis regresi yang digunakan dalam penelitian ini adalah regresi linier berganda dengan Moderated Regression Analysis (MRA) untuk mengetahui gambaran mengenai pengaruh likuiditas, leverage dan profitabilitas terhadap nilai perusahaan dengan kebijakan dividen sebagai pemoderasi. Hasil analisis regresi dapat dilihat pada tabel berikut:

Tabel 9. Analisis Regresi Berganda dengan MRA Persamaan 1

Coefficients $^{\mathbf{a}}$

\begin{tabular}{|c|c|c|c|c|c|c|}
\hline & \multirow[b]{2}{*}{ Model } & \multicolumn{2}{|c|}{$\begin{array}{c}\text { Unstandardized } \\
\text { Coefficients }\end{array}$} & \multirow{2}{*}{$\begin{array}{c}\begin{array}{c}\text { Standardized } \\
\text { Coefficients }\end{array} \\
\text { Beta }\end{array}$} & \multirow[b]{2}{*}{$\mathrm{t}$} & \multirow[b]{2}{*}{ Sig. } \\
\hline & & $\mathrm{B}$ & Std. Error & & & \\
\hline \multirow[t]{4}{*}{1} & (Constant) & -3.875 & 1.476 & & -2.626 & .009 \\
\hline & Likuiditas(CR) & .360 & .178 & .198 & 2.017 & .045 \\
\hline & Leverage (DER) & .362 & .138 & .258 & 2.633 & .009 \\
\hline & $\begin{array}{l}\text { Profitabilitas } \\
\text { (ROE) }\end{array}$ & .523 & .078 & .430 & 6.706 & .000 \\
\hline
\end{tabular}

a. Dependent Variable: Nilai Perusahaan (PBV)

Tabel 10. Analisis Regresi Berganda dengan MRA Persamaan 2

\section{Coefficients $^{\text {a }}$}

\begin{tabular}{|c|c|c|c|c|c|c|}
\hline & \multirow[b]{2}{*}{ Model } & \multicolumn{2}{|c|}{$\begin{array}{l}\text { Unstandardized } \\
\text { Coefficients }\end{array}$} & \multirow{2}{*}{$\begin{array}{c}\begin{array}{c}\text { Standardized } \\
\text { Coefficients }\end{array} \\
\text { Beta }\end{array}$} & \multirow[b]{2}{*}{$\mathrm{t}$} & \multirow[b]{2}{*}{ Sig. } \\
\hline & & $\mathrm{B}$ & Std. Error & & & \\
\hline \multirow[t]{5}{*}{1} & (Constant) & -6.051 & 1.468 & & -4.122 & .000 \\
\hline & Likuiditas(CR) & .457 & .170 & .252 & 2.689 & .008 \\
\hline & Leverage (DER) & .451 & .132 & .321 & 3.428 & .001 \\
\hline & Profitabilitas (ROE) & .589 & .075 & .484 & 7.839 & .000 \\
\hline & $\begin{array}{c}\text { Kebijakan Dividen } \\
\text { (DPR) }\end{array}$ & .328 & .068 & .300 & 4.835 & .000 \\
\hline
\end{tabular}

a. Dependent Variable: Nilai Perusahaan (PBV)

Tabel 11. Analisis Regresi Berganda dengan MRA Persamaan 3

Coefficients $^{\text {a }}$

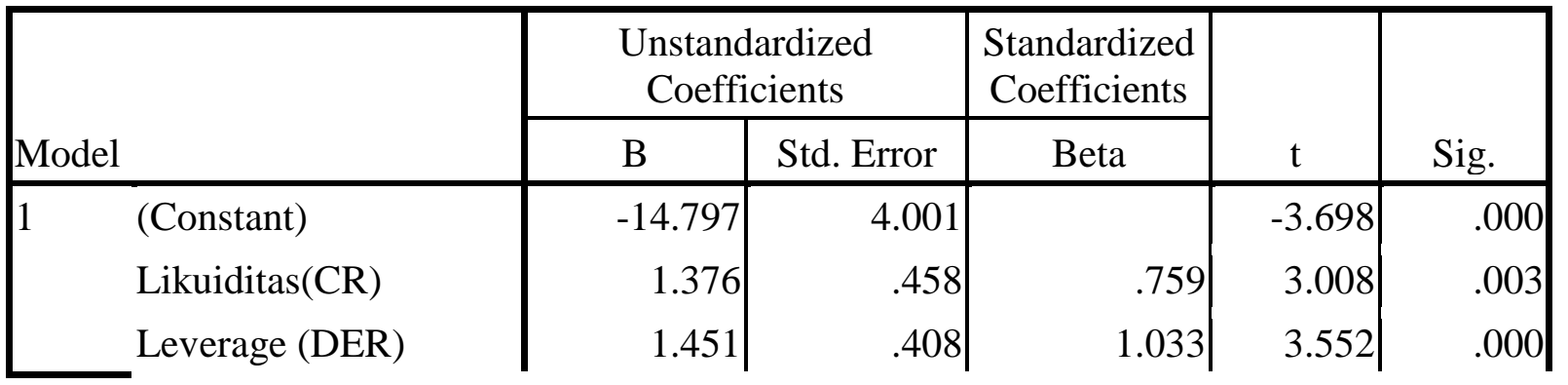




\begin{tabular}{|c|c|c|c|c|c|}
\hline Profitabilitas (ROE) & .403 & .178 & .331 & 2.263 & .025 \\
\hline $\begin{array}{l}\text { Kebijakan Dividen } \\
\text { (DPR) }\end{array}$ & 3.148 & 1.184 & 2.872 & 2.658 & .009 \\
\hline $\mathrm{X} 1 * \mathrm{Z}$ & -.302 & .136 & -1.608 & -2.213 & .028 \\
\hline $\mathrm{X} 2 * \mathrm{Z}$ & -.311 & .119 & -1.403 & -2.615 & .010 \\
\hline $\mathrm{X} 3 * \mathrm{Z}$ & .050 & .043 & .190 & 1.154 & .250 \\
\hline
\end{tabular}

a. Dependent Variable: Nilai Perusahaan (PBV)

Berdasarkan hasil analisis regresi pada beberapa tabel diatas, dapat dilihat apakah variabel moderasi benar sebagai pure moderator, quasi moderatorpredictor moderasi atau potensial moderasi.

a. Moderasi 1

Pada tabel moderasi 1 menunjukkan bahwa Z (kebijakan dividen) berpengaruh terhadap Y (nilai perusahaan) dengan tingkat signifikansi 0,000 atau lebih kecil dari 0,05, sedangkan pada tabel 4.8 intraksi $\mathrm{Z}^{*} \mathrm{X} 1$ (moderasi 1 antara likuiditas dengan kebijakan dividen) juga signifikan $(0,028<0,05)$, dengan demikian dapat disimpulkan bahwa variabel moderasi merupakan quasi moderasi. Menurut Satrianto (2020), quasi moderasi merupakan variabel yang memoderasi hubungan antara variabel independen dan variabel dependen, dimana variabel moderasi quasi berintraksi dengan variabel dependen sekaligus menjadi variabel independen.

b. Moderasi 2

Pada intraksi $Z * X 2$ (moderasi 2 antara leverage dengan kebijakan dividen) juga signifikan $(0,010<0,05)$, maka disimpulkan bahwa variabel moderasi merupakan variabel quasi moderasi. Menurut Satrianto (2020), quasi moderasi merupakan variabel yang memoderasi hubungan antara variabel independen dan variabel dependen, dimana variabel moderasi quasi berintraksi dengan variabel dependen sekaligus menjadi variabel independen. Hal ini dilihat dari pengaruh $\mathrm{Z}$ terhadap $\mathrm{Y}$ pada persamaan pertama signifikan dan pengaruh intraksi $Z^{*} \mathrm{X} 1$ dan $\mathrm{Z} * \mathrm{X} 2$ pada persamaan kedua juga signifikan.

c. Moderasi 3

Pada intraksi $\mathrm{Z}^{*} \mathrm{X} 3$ (moderasi 3 antara profitabilitas dengan kebijakan dividen) tidak signifikan atau lebih besar dari 0,05 (0,250 >0,05). Dengan demikian dapat disimpulkan bahwa variabel moderasi merupakan predictor moderasi. Menurut Satrianto (2020), prediktor moderasi merupakan variabel moderasi yang hanya berperan sebagai variabel independen dalam model hubungan yang dibentuk. Dimana pengaruh dari $\mathrm{Z}$ terhadap $\mathrm{Y}$ pada persamaan pertama signifikan sedangkan intraksi $Z^{*} \mathrm{X} 3$ pada persamaan kedua tidak signifikan. Sehingga dalam penelitian ini pada intraksi $Z^{*} X 3$ (moderasi 3 antara profitabilitas dengan kebijakan dividen), kebijakan dividen hanya berperan sebagai variabel independen dalam model hubungan yang dibentuk dan kebijakan dividen tidak berintraksi dengan profitabilitas.

Berdasarkan uraian diatas, jenis moderasi dalam penelitan adalah quasi moderasi dan prediktor moderasi, dimana moderasi antara likuiditas dan kebijakan dividen merupakan quasi moderasi, leverage dan kebijakan dividen juga merupakan quasi moderasi, yaitu variabel yang berintraksi dengan variabel dependen sekaligus menjadi variabel independen sedangkan untuk profitabilitas dengan kebijakan dividen merupakan prediktor moderasi yaitu variabel moderasi yang hanya berperan sebagai variabel independen dalam model penelitian yang dibentuk.

\section{Pengujian Hipotesis}

\section{a. Uji Statistik t (Parsial)}


Secara parsial atau uji statistik t merupakan uji yang digunakan untuk melihat seberapa jauh pengaruh pengaruh variabel independen dengan variabel dependen. Menurut Ghozali (2013), uji t-statistik pada dasarnya menunjukkan besarnya pengaruh suatu variabel bebas dalam menjelaskan perubahan variabel terikat. Tingkat signifikansi untuk pengujian ini adalah $0,05(\alpha=5 \%)$. Terima atau tolak hipotesis dengan ketentuan sebagai berikut:

- Jika nilai signifikan >0,05 maka hipotesis ditolak. Artinya secara parsial variabel independen tidak berpengaruh signifikan terhadap variabel dependen.

- Jika nilai signifikan $\leq 0,05$ maka hipotesis diterima. Artinya secara parsial variabel independen berpengaruh signifikan terhadap variabel dependen.

Tabel 12. Uji Statistik t (Parsial)

Coefficients ${ }^{\mathrm{a}}$

\begin{tabular}{|c|c|c|c|c|c|c|}
\hline \multirow{2}{*}{\multicolumn{2}{|c|}{ Model }} & \multicolumn{2}{|c|}{$\begin{array}{c}\text { Unstandardized } \\
\text { Coefficients }\end{array}$} & \multirow{2}{*}{$\begin{array}{c}\begin{array}{c}\text { Standardized } \\
\text { Coefficients }\end{array} \\
\text { Beta }\end{array}$} & \multirow[b]{2}{*}{$\mathrm{T}$} & \multirow[b]{2}{*}{ Sig. } \\
\hline & & B & Std. Error & & & \\
\hline \multirow[t]{4}{*}{1} & (Constant) & -3.875 & 1.476 & & -2.626 & .009 \\
\hline & Likuiditas(CR) & .360 & .178 & .198 & 2.017 & .045 \\
\hline & Leverage (DER) & .362 & .138 & .258 & 2.633 & .009 \\
\hline & $\begin{array}{l}\text { Profitabilitas } \\
\text { (ROE) }\end{array}$ & .523 & .078 & .430 & 6.706 & .000 \\
\hline
\end{tabular}

a. Dependent Variable: Nilai Perusahaan (PBV)

Berdasarkan tabel diatas, menunjukkan hasil analisis regresi untuk menguji $\mathrm{H} 1, \mathrm{H} 2$ dan $\mathrm{H} 3$ sebagai berikut:

1) Pengaruh likuiditas terhadap nilai perusahaan.

Berdasarkan pengujian hipotesis uji statistik $\mathrm{t}$ (parsial) pengaruh likuiditas terhadap nilai perusahaan pada tabel 4.9 diperoleh tingkat signifikansi sebesar 0.045 atau lebih kecil dari $0,05(\alpha=5 \%)$ maka H1 terbukti. Artinya, likuiditas berpengaruh positif signifikan terhadap nilai perusahaan.

2) Pengaruh leverage terhadap nilai perusahaan.

Berdasarkan pengujian hipotesis uji statistik $t$ (parsial) pengaruh leverage terhadap nilai perusahaan pada tabel 4.9 diperoleh tingkat signifikansi sebesar 0.009 atau lebih kecil dari $0,05(\alpha=5 \%)$. Maka H2 terbukti. Artinya, leverage berpengaruh positif signifikan terhadap nilai perusahaan.

3) Pengaruh profitabilitas terhadap nilai perusahaan.

Berdasarkan pengujian hipotesis uji statistik t (parsial) pengaruh profitabilitas terhadap nilai perusahaan pada tabel 4.9 diperoleh tingkat signifikansi sebesar 0.000 atau lebih kecil dari $0,05(\alpha=5 \%)$. Maka H3 terbukti. Artinya, profitabilitas berpengaruh positif signifikan terhadap nilai perusahaan.

b. Uji Intraksi / Moderated Regression Analysis (MRA)

Moderated Regression Analysis (MRA) merupakan aplikasi khusus regresi linear berganda yang didalamnya mengandung unsur interaksi yang dihasilkan dari perkalian dua atau lebih variabel independen (Ghozali, 2013:219). Pengambilan keputusan didasarkan pada pengaruh hubungan antara variabel independen dengan variabel dependen dapat dilihat dari taraf signiifikansinya yaitu 0,05 (Ghozali, 2013:211):

- Jika nilai signifikan $>0,05$ maka hipotesis ditolak.

- Jika nilai signifikan $\leq 0,05$ maka hipotesis diterima. 
Tabel 13. Uji Intraksi/ Moderated Regression Analysis (MRA)

Coefficients $^{\mathrm{a}}$

\begin{tabular}{|c|c|c|c|c|c|}
\hline \multirow{2}{*}{} & \multicolumn{2}{|c|}{$\begin{array}{c}\text { Unstandardized } \\
\text { Coefficients }\end{array}$} & $\begin{array}{c}\text { Standardized } \\
\text { Coefficients }\end{array}$ & & \\
\cline { 2 - 5 } Model & $\mathrm{B}$ & Std. Error & Beta & $\mathrm{t}$ & Sig. \\
\hline (Constant) & -14.797 & 4.001 & & -3.698 & .000 \\
Likuiditas(CR) & 1.376 & .458 & .759 & 3.008 & .003 \\
Leverage (DER) & 1.451 & .408 & 1.033 & 3.552 & .000 \\
Profitabilitas (ROE) & .403 & .178 & .331 & 2.263 & .025 \\
Kebijakan Dividen & 3.148 & 1.184 & 2.872 & 2.658 & .009 \\
(DPR) & -.302 & .136 & -1.608 & -2.213 & .028 \\
$\mathrm{X} 1 * \mathrm{Z}$ & -.311 & .119 & -1.403 & -2.615 & .010 \\
$\mathrm{X} 2 * \mathrm{Z}$ & .050 & .043 & .190 & 1.154 & .250 \\
$\mathrm{X} 3 * \mathrm{Z}$ & & & & \\
\hline
\end{tabular}

a. Dependent Variable: Nilai Perusahaan (PBV)

Berdasarkan tabel diatas, menunjukkan hasil analisis regresi untuk menguji H4, H5 dan H6 sebagai berikut:

1) Pengaruh likuiditas terhadap nilai perusahaan dimoderasi oleh kebijakan dividen. Berdasarkan pengujian hipotesis uji intraksi/Moderated Regression Analysis (MRA) pengaruh likuiditas terhadap nilai perusahaan dimoderasi oleh kebijakan dividen pada tabel diatas diperoleh tingkat signifikansi sebesar 0.028 atau lebih kecil dari $0,05(\alpha=5 \%)$ dengan koefisien intraksi sebesar -0.302. Maka H4 tidak terbukti. Artinya, kebijakan dividen tidak mampu memperkuat pengaruh likuiditas terhadap nilai perusahaan.

2) Pengaruh leverage terhadap nilai perusahaan dimoderasi oleh kebijakan dividen. Berdasarkan pengujian hipotesis uji intraksi/Moderated Regression Analysis (MRA) pengaruh leverage terhadap nilai perusahaan dimoderasi oleh kebijakan dividen pada tabel 4.10 diperoleh tingkat signifikansi sebesar 0.010 atau lebih kecil dari $0,05(\alpha=5 \%)$ dengan koefisien intraksi -0.311. Maka H5 terbukti. Artinya, kebijakan dividen mampu memperlemah pengaruh leverage terhadap nilai perusahaan.

3) Pengaruh profitabilitas terhadap nilai perusahaan dimoderasi oleh kebijakan dividen. Berdasarkan pengujian hipotesis intraksi/Moderated Regression Analysis (MRA) pengaruh profitabilitas terhadap nilai perusahaan dimoderasi oleh kebijakan dividen pada tabel 4.10 diperoleh tingkat signifikansi sebesar 0.250 atau lebih kecil dari $0,05(\alpha=5 \%)$ dengan koefisien intraksi sebesar 0.050. Maka H6 tidak terbukti. Artinya, kebijakan dividen tidak mampu memperkuat pengaruh profitabilitas terhadap nilai perusahaan yang ditunjukkan dengan nilai tingkat signifikansi yang lebih besar dari 0,05 .

\section{Uji F (Uji kelayakan model)}

Menurut Ghozali (2011), uji goodness of fit (uji kelayakan model) dilakukan untuk mengukur ketepatan fungsi regresi sampel dalam menaksirkan nilai aktual secara statistic. Model goodness of fit dapat diukur dari nilai statistik F yang menunjukkan apakah semua variabel independen yang dimasukkan dalam model mempunyai pengaruh secara bersamasama terhadap variabel dependen. 
- Jika nilai signifikan $>0,05$, maka model regresi dinyatakan tidak layak atau tidak dapat digunakan untuk menjelaskan pengaruh variabel independen terhadap variabel dependen.

- Jika nilai signifikan $\leq 0,05$ maka model regresi dinyatakan layak atau dapat digunakan untuk menjelaskan pengaruh variabel independen terhadap variabel dependen.

Tabel 14. Uji Statistik F ( uji kelayakan model)

ANOVA $^{b}$

\begin{tabular}{|ll|r|r|r|r|r|}
\hline \multicolumn{2}{|l|}{ Model } & \multicolumn{1}{|c|}{$\begin{array}{c}\text { Sum of } \\
\text { Squares }\end{array}$} & df & Mean Square & F & Sig. \\
\hline 1 & Regression & 65.241 & 3 & 21.747 & 17.318 & $.000^{\mathrm{a}}$ \\
& Residual & 243.613 & 194 & 1.256 & & \\
& Total & 308.854 & 197 & & & \\
\hline
\end{tabular}

a. Predictors: (Constant), Profitabilitas (ROE), Leverage (DER), Likuiditas(CR)

b. Dependent Variable: Nilai Perusahaan (PBV)

Berdasarkan hasil analisis regresi pada tabel diatas, pengujian hipotesis uji statistik F (Uji kelayakan model) diperoleh F-hitung sebesar 17.318 dengan tingkat signifikansi sebesar 0.000 atau lebih kecil dari $0,05(\alpha=5 \%)$. Artinya penelitian yang bertujuan untuk melihat Pengaruh likuiditas, leverage dan profitabilitas terhadap nilai perusahaan dengan kebijakan dividen sebagai variabel moderasi pada perusahaan Manufakktur yang terdaftar di Bursa Efek Indonesia (BEI) ini dinyatakan layak dan hasil ini menunjukkan bahwa model regresi yang digunakan dapat dikatakan memenuhi asumsi kelayakan sebuah model penelitian dengan data penelitian yang dianalisis.

\section{Uji $R^{2}$ ( Koefisien Derterminasi)}

Koefisien determinasi bertujuan untuk mengukur seberapa jauh kemampuan model dalam menerangkan variasi variabel dependen. Nilai koefisien determinasi berada pada kisaran 0 sampai 1. Nilai $\mathrm{R}$ yang lebih kecil menunjukkan bahwa variabel independen memiliki kemampuan yang sangat terbatas dalam menjelaskan perubahan variabel dependen, begitu pula sebaliknya.

Tabel 15. Uji $R^{2}$ (Koefisien Derterminasi) Sebelum Moderasi

Model Summary

\begin{tabular}{|l|c|r|r|r|}
\hline Model & R & R Square & $\begin{array}{c}\text { Adjusted R } \\
\text { Square }\end{array}$ & $\begin{array}{l}\text { Std. Error of } \\
\text { the Estimate }\end{array}$ \\
\hline 1 & $.460^{\mathrm{a}}$ & .211 & .199 & 1.12060 \\
\hline
\end{tabular}

a. Predictors: (Constant), Profitabilitas (ROE), Leverage

(DER), Likuiditas(CR)

Berdasarkan tabel diatas nilai koefisien determinasi pada $R$ Square (R2) sebesar 0,211 atau 21,1\%. Dapat disimpulkan bahwa nilai perusahaan (Y) dipengaruhi oleh likuiditas (X1), leverage (X2) dan profitabilitas (X3) sebesar $21,1 \%$ sedangkan sisanya $78,9 \%$ dijelaskan oleh faktor lain yang tidak masuk dalam penelitian ini.

Tabel 16. Uji $R^{2}$ (Koefisien Derterminasi) Setelah Moderasi

Model Summary

\begin{tabular}{|c|c|c|c|c|}
\hline Model & R & R Square & $\begin{array}{c}\text { Adjusted R } \\
\text { Square }\end{array}$ & $\begin{array}{c}\text { Std. Error of } \\
\text { the Estimate }\end{array}$ \\
\hline
\end{tabular}




\begin{tabular}{|l|r|r|r|r|}
\hline 1 & $.572^{\mathrm{a}}$ & .327 & .302 & 1.04575 \\
\hline
\end{tabular}

a. Predictors: (Constant), X3*Z, Leverage (DER),

Kebijakan Dividen (DPR), Likuiditas(CR), Profitabilitas

(ROE), $\mathrm{X} 2 * \mathrm{Z}, \mathrm{X} 1 * \mathrm{Z}$

Berdasarkan tabel diatas nilai koefisien determinasi pada $R$ Square (R2) sebesar 0,327 atau $32,7 \%$ atau meningkat dengan adanya variabel moderasi. Dapat disimpulkan bahwa variabel dependen yaitu nilai perusahaan $(\mathrm{Y})$ dapat dijelaskan oleh variabel independen yaitu likuiditas (X1), leverage (X2), profitabilitas (X3) dan variabel moderasi yaitu kebijakan dividen (Z), serta intraksi variabel independen dengan variabel moderasi sebesar $32,7 \%$ sedangkan sisanya $67,3 \%$ dijelaskan oleh faktor lain yang tidak masuk dalam penelitian ini.

\subsection{Pembahasan}

Berdasarkan hasil pengujian hipotesis yang dilakukan, diperoleh hasil bahwa likuidittas, leverage dan profitabilitas berpengaruh positif signifikan terhadap nilai perusahaan. Kemudian dalam penggunaan kebijakan dividen sebagai variabel moderasi menunjukkan bahwa hanya pengaruh profitabilitas terhadap nilai perusahaan yang tidak mampu dimoderasi oleh kebijakan dividen. Sedangkan likuiditas dan leverage terhadap nilai perusahaan mampu dimoderasi oleh kebijakan dividen. Hasil penelitian tersebut dapat diuraikan sebagai berikut:

\section{Pengaruh likuiditas terhadap nilai perusahaan}

Likuiditas diproksikan oleh Current Rasio (CR) dalam penelitian ini. Dimana terlihat bahwa hasil menunjukkan tingkat signifikasi sebesar 0.003 atau lebih kecil dari $0,05(\alpha=5 \%)$. Artinya, secara parsial likuiditas berpengaruh positif signifikan terhadap nilai perusahaan Manufaktur yang terdaftar di Bursa Efek Indonesia (BEI) pada tahun 2017-2019. Sehingga pertama dalam penelitian ini terbukti. Hasil tersebut mengindikasikan bahwa semakin tinggi tingkat likuiditas maka nilai perusahaan juga tinggi.

Hasil penelitian ini sejalan dengan penjelasan Signaling Theory yang menjelaskan bahwa tingkat kemampuan perusahaan dalam memenuhi kewajiban jangka pendeknya akan mendapatkan respon positif oleh pasar yang mengakibatkan nilai perusahaan naik atau likuiditas dapat memberi sinyal kepada pemegang saham terkait informasi yang diberikan. Hasil penelitian ini juga sejalan dengan pendapat Sartono (2010) yang menjelaskan bahwa Likuiditas sangat erat kaitannya dengan nilai perusahaan. Perusahaan yang likuid akan dipercaya oleh investor karena perusahaan dapat melunasi semua utangnya tepat waktu, namun di sisi lain, perusahaan yang likuid biasanya cenderung menggunakan dana internal dibanding dana eksternal berupa hutang. Dengan demikian, hal ini dapat dikatakan bahwa para pemegang saham memperhatikan likuiditas perusahaan.

Hasil penelitian ini sejalan dengan penelitian yang dilakukan oleh Lestari (2015), Mery (2017), Putra \& Lestari (2016), Ihsan, dkk (2018) dengan hasil penelitian bahwa likuiditas berpengaruh positif signifikan terhadap nilai perusahaan.

\section{Pengaruh leverage terhadap nilai perusahaan}

Dalam penelitian ini leverage diproksikan oleh Debt to Equity Ratio (DER). Dimana hasil penelitian menunjukkan bahwa tingkat signifikasi sebesar 0.000 atau lebih kecil dari $0,05(\alpha=$ $5 \%)$. Artinya, secara parsial leverage berpengaruh positif signifikan terhadap nilai perusahaan Manufaktur yang terdaftar di Bursa Efek Indonesia (BEI) pada tahun 2017-2019. Sehingga hipotesis kedua dalam penelitian ini terbukti. Hasil tersebut mengidentifikasikan bahwa semakin tinggi leverage menunjukkan bahwa nilai perusahaan juga tinggi.

Hasil ini sejalan dengan teori yang dikemukakan oleh Modigliani dan Miller (MM) yang mengemukakan bahwa jika suatu perusahaan dikenakan pajak penghasilan, penggunaan hutang merupakan keputusan yang tepat bagi perusahaan untuk meningkatkan nilai perusahaan. Hal ini terjadi karena adanya pelunasan bunga pinjaman dapat mengurangi beban biaya yang 
seharusnya dialokasikan untuk membayar pajak. Melalui kegiatan ini nilai EAT dapat ditingkatkan sehingga dapat meningkatkan laba perusahaan dan penilaian pasar terhadap perusahaan (Husnan, 2006:269). Hasil ini juga sejalan dengan pendapat Hanafi (2011:316) yang menyatakan bahwa pemakaian hutang diharapkan oleh suatu perusahaan mendapat respon positif oleh pihak luar ataupun investor karena merupakan sinyal yang positif untu peningkatan nilai perusahaan. Hal tersebut mencerminkan penilaian oleh investor terhadap nilai perusahaan apabila perusahaan tersebut meningkatkan proporsi hutangnya. Dengan demikian, hal ini dapat dikatakan bahwa seorang investor memperhatikan besar kecilnya hutang yang dimiliki oleh perusahaan dan memperhatikan bagaimana pihak manajemen dalam menggunakan danauntuk mencapai nilai tambah bagi perusahaan.

Hasil penelitian ini sejalan dengan penelitian yang dilakukan oleh Putra \& Lestari (2016), Mery (2017), Lestari (2015), Putri \& Ukhriwati (2016) dan Rahmawati (2017) dengan hasil penelitian leverage berpengaruh positif signifikan terhadap nilai perusahaan.

Pengaruh profitabilitas terhadap nilai perusahaan

Dalam penelitian ini profitabilitas diproksikan oleh Return on Equity (ROE). Dimana hasil penelitian menunjukkan bahwa tingkat signifikasi sebesar 0.025 atau lebih kecil dari 0,05 $(\alpha=5 \%)$. Artinya, secara parsial profitabilitas berpengaruh positif signifikan terhadap nilai perusahaan Manufaktur yang terdaftar di Bursa Efek Indonesia (BEI) pada tahun 2017-2017. Sehingga dalam penelitian ini hipotesis ketiga terbukti. Hasil tersebut mengindikasikan bahwa semakin tinggi tingkat profitabilitas maka nilai perusahaan juga tinggi.

Hasil penelitian ini sejalan dengan penjelasan Signaling Theory yang menjelaskan bahwa keuntungan yang diperoleh perusahaan menjadi sinyal bagi manajemen untuk menunjukkan kepada investor tentang prospek perusahaan yang secara langsung akan mempengaruhi nilai perusahaan. Hasil penelitian ini juga sejalan dengan pendapat Husnan (2009:317), yang menyatakan bahwa Profitabilitas yang tinggi menunjukkan prospek perusahaan yang baik, sehingga investor akan merespon positif dan nilai perusahaan akan meningkat. Dengan demikian, hal ini dapat dikatakan bahwa seorang investor memperhatikan profitabilitas suatu perusahaan.

Hasil penelitian ini sejalan dengan penelitian yang dilakukan oleh Putrac\& Lestari (2016), Mery (2017) dan Rahmawati (2017), Prasetya (2020), Putri \& Ukhriwati (2016), Prasetyorini (2013), Sisca (2016), Ihsan dkk (2018), Jariah (2016) dan Anggraeni \& Sulhan (2020) dengan hasil penelitian profitabilitas berpengaruh positif signifikan terhadap nilai perusahaan.

Pengaruh likuiditas terhadap nilai perusahaan yang dimoderasi oleh kebijakan dividen

Dalam penelitian ini kebijakan dividen diproksikan oleh Dividen Payout Ratio (DPR). Hasil uji intraksi/MRA dalam penelitian ini menunjukkan bahwa tingkat signifikansi sebesar 0.028 atau lebih kecil dari $0,05(\alpha=5 \%)$ dengan tingkat koefisien intraksi sebesar -0.302 (negative). Artinya, kebijakan dividen tidak mampu memperkuat pengaruh likuiditas terhadap nilai perusahaan Manufaktur yang terdaftar di Bursa Efek Indonesia (BEI) pada tahun 20172019. Sehingga dalam penelitian ini hipotesis keempat tidak terbukti.

Hasil analisis menunjukkan bahwa kebijakan dividen mampu berperan sebagai moderator (memperlemah) pengaruh likuiditas terhadap nilai perusahaan yang ditunjukkan oleh koefisien intraksi -0.302 (negatif). Artinya, adanya kebijakan dividen memperlemah pengaruh likuiditas terhadap nilai perusahaan. Dengan kata lain, kebijakan dividen tidak dapat memperkuat pengaruh likuiditas terhadap nilai perusahaan. Perusahaan harus terlebih dahulu menggunakan asetnya untuk membayar hutang jangka pendek. Jika perusahaan memilih untuk membagikan dividen terlebih dahulu kepada pemegang saham, maka kemampuan perusahaan dalam memenuhi hutang jangka pendeknya tidak dipenuhi. Likuiditas yang rendah akan menurunkan nilai perusahaan. Dengan demikian kebijakan dividen memperlemah pengaruh 
likuiditas terhadap nilai perusahaan. Hasil penelitian ini berbeda dengan penjelasan Agency Theory, yang menjelaskan ketika likuiditas tinggi kemudian perusahaan membayarkan dividen kepada pemegang saham artinya perusahaan mengembalikan apa yang menjadi hak investor atau pemegang saham yang berdampak terhadap peningkatan nilai perusahaan.

Hasil penelitian ini sejalan dengan penelitian yang dilakukan oleh Putra\&Prasetya (2020), Lestari (2015) dengan hasil penelitian kebijakan dividen mampu memoderasihubungan pengaruh likuiditas terhadap nilai perusahaan.

Pengaruh leverage terhadap nilai perusahaan yang dimoderasi oleh kebijakan dividen

Dalam penelitian ini kebijakan dividen diproksikan oleh Dividen Payout Ratio(DPR). Hasil uji intraksi/MRA dalam penelitian ini menunjukkan bahwa tingkat signifikasi sebesar 0.010 atau lebih kecil dari $0,05(\alpha=5 \%)$ dengan koefisien intraksi sebesar -0.311 . Artinya, kebijakan dividen memperlemah pengaruh leverage terhadap nilai perusahaan Manufaktur yang terdaftar di Bursa Efek Indonesia (BEI) pada tahun 2017-2019. Sehingga dalam penelitian ini hipotesis kelima terbukti.

Hasil ini sejalan dengan pandangan Brigham \& Houston (2011) yang menyatakan bahwa pihak luar mengartikan peningkatan hutang sebagai kemampuan perusahaan untuk membayar kewajiban di masa depan, yang akan mendapat respon positif dari pasar. Berdasarkan teori ketidakrelevan dividen, dividen payout ratio tidak mempengaruhi nilai perusahaan. Tetapi, hanya dipengaruhi oleh profitabilitas dasar dan risiko usahanya dengan syarat bahwa dividen yang dibayarkan tidak dikenakan pajak penghasilan. Hasil ini juga sejalan dengan pendapat (Ihsan, dkk, 2018), semakin tinggi tingkat penggunaan hutang yang dimiliki oleh perusahaan, maka semakin kecil pula kemampuan perusahaan dalam memenuhi kewajibannya kepada pemegang saham dalam bentuk dividen, dan penilaian seorang investor akan semakin buruk terhadap perusahaan tersebut dan akan berdampak pada penurunan terhadap nilai perusahaan. Dengan demikian, hal ini dapat dikatakan bahwa investor memperhatikan kebijakan dividen dan leverage perusahaan.

Hasil penelitian ini sejalan dengan penelitian yang dilakukan oleh Putra\& Anggraeni \& Sulhan (2020), Jariah (2016) dan Rahmawati (2017), Lestari (2015) dengan hasil penelitian kebijakan dividen mampu memoderasi (memperlemah) hubungan pengaruh leverage terhadap nilai perusahaan.

Pengaruh profitabilitas terhadap nilai perusahaan yang dimoderasi oleh kebijakan dividen

Dalam penelitian ini kebijakan dividen diproksikan oleh Dividen Payout Ratio (DPR). Hasil uji intraksi/MRA dalam penelitian ini menunjukkan bahwa tingkat signifikansi sebesar 0.250 atau lebih besar dari $0,05(\alpha=5 \%)$ dengan koefisien intraksi sebesar 0.050 . Artinya, kebijakan dividen tidak mampu memperkuat pengaruh profitabilitas terhadap nilai perusahaan Manufaktur yang terdaftar di Bursa Efek Indonesia (BEI) pada tahun 2017-2019. Sehingga dalam penelitian ini hipotesis keenam tidak terbukti.

Pembagian dividen dikaitkan dengan laba yang diperoleh perusahaan tersedia bagi pemegang saham. Laba ini ditunjukkan dalam laporan laba rugi yang disebut sebagai laba setelah pajak (Earning After Tax). Pada umumnya sebagian EAT dibagi dalam bentuk dividen dan sebagian lagi diinvestasikan kembali. Adanya pembagian dividen yang diberikan kepada pemegang saham berdampak terhadap naik turunnya harga saham. Semakin tinggi laba yang dimiliki oleh perusahaan semakin tinggi pula dividen yang dibayarkan kepada pemegang saham dan mempengaruhi tingginya harga saham suatu perusahaan. Hal tersebut menunjukkan bahwa besar kecilnya EAT yang dimiliki oleh perusahaan mempengaruhi besar kecilnya dividen yang dibayarkan kepada pemegang saham dan berdampak tehadap naik turunnya harga saham suatu perusahaan. 
Hasil analisis menunjukkan bahwa kebijakan dividen tidak mampu memperkuat pengaruh profitabilitas terhadap nilai perusahaan yang ditunjukkan dengan tingkat signifikansi yang lebih besar dari $0.05(0.250>0.05)$. Hal ini menunjukkan bahwa tingkat profitabilitas dapat memberikan sinyal positif kepada investor tentang nilai perusahaan, namun, ketika profitabilitas meningkat kebijakan dividen tidak selalu dapat memperkuat penilaian investor terhadap saham perusahaan.

Hasil ini sesuai dengan teori ketidakrelevan dividen yang dikemukakan oleh Merton Miller dan Franco Modiglami (MM), yang menyatakan bahwa nilai suatu perusahaan tidak dipengaruhi oleh besar kecilnya Dividen Payout Ratio (DPR) tetapi hanya dipengaruhi oleh bagaimana perusahaan mengelola aset untuk memperoleh laba. Semua pihak baik manajer maupun pemegang saham memiliki informasi yang sama tentang laba perusahaan di masa yang akan datang (Brigham \& Houston, 2011:211). Dengan demikian adanya pembayaran dividen tidak dapat memperkuat pengaruh profitabilitas terhadap nilai perusahaan. Hasil penelitian ini sejalan dengan penelitian yang dilakukan oleh Sisca (2016) dengan hasil penelitian kebijakan dividen tidak mampu memoderasi hubungan pengaruh profitabilitas terhadap nilai perusahaan.

\section{KESIMPULAN DAN SARAN}

\subsection{Kesimpulan}

Berdasarkan hasil penelitian dan pembahasan maka dapat ditarik kesimpulan sebagai berikut:

a. Likuiditas berpengaruh positif signifikan terhadap nilai perusahaan Manufaktur yang terdaftar di Bursa Efek Indonesia (BEI) tahun 2017-2019.Likuiditas yang tinggi membuat pasar percayaterhadap prospek perusahaan dan berdampak pada kinerja perusahaan yang baik. Dan kinerja perusahaan yang baik membuat nilai perusahaan tinggi.

b. Leverage berpengaruh positif signifikan terhadap nilai perusahaan Manufaktur yang terdaftar di Bursa Efek Indonesia (BEI) tahun 2017-2019. Peningkatan hutang merupakan tanda atau sinyal positif untuk meningkatkan nilai perusahaan dimata investor karena melalui kegiatan ini nilai EAT dapat ditingkatkan sehingga dapat meningkatkan laba perusahaan dan penilaian pasar terhadap perusahaan.

c. Profitabilitas berpengaruh positif signifikan terhadap nilai perusahaan Manufaktur yang terdaftar di Bursa Efek Indonesia (BEI) tahun 2017-2019. Profitabilitas yang tinggi menunjukkan prospek perusahaan yangbaik, sehingga investor akan merespon positif dan nilai perusahaan akan meningkat.

d. Kebijakan dividen tidak mampu memperkuat pengaruh likuiditas terhadap nilai perusahaan Manufaktur yang terdaftar di Bursa Efek Indonesia (BEI) tahun 2017-2019. Kas akan dibagikan kepada pemegang saham dalam bentuk dividen. Likuiditas yang rendah akan menurunkan nilai perusahaan karena jika perusahaan memilih untuk membagikan dividen kepada pemegang saham, maka tidak akan mampu membayar hutang jangka pendek.

e. Kebijakan dividen memperlemah pengaruh leverage terhadap nilai perusahaan Manufaktur yang terdaftar di Bursa Efek Indonesia (BEI) tahun 2017-2019. semakin tinggi tingkat penggunaan hutang yang dimiliki oleh perusahaan, maka semakin kecil pula kemampuan perusahaan dalam memenuhi kewajibannya kepada pemegang saham dalam bentuk dividen, dan penilaian seorang investor akan semakin buruk terhadap perusahaan tersebut dan akan berdampak pada penurunan terhadap nilai perusahaan

f. Kebijakan dividen tidak mampu memperkuat pengaruh profitabilitas terhadap nilai perusahaan Manufaktur yang terdaftar di Bursa Efek Indonesia (BEI) tahun 2017-2019. Tingkat profitabilitas dapat memberikan sinyal positif kepada investor tentang nilai perusahaan, namun, ketika profitabilitas meningkat kebijakan dividen tidak selalu dapat memperkuat penilaian investor terhadap saham perusahaan.

\section{SARAN}

2144 | Kebijakan Dividen Sebagai Pemoderasi Dan Pengaruhnya Terhadap Likuiditas, Leverage Dan Profitabilitas Pada Nilai Perusahaan (Parida) 
Berdasarkan hasil penelitian yang dilakukan, maka dapat diberikan saran sebagai berikut :

a. Disarankan untuk peneliti berikutnya yang akan melakukan penelitian dengan variabel yang sama hendaknya dapat menambah faktor lain yang dapat mempengaruhi nilai perusahaan seperti rasio manajemen aset, keputusan investasi dan keputusan pendanaan dan juga memperhatikan likuiditas dan profitabilitas perusahaan.

b. Memperluas sampel penelitian misalnya memperpanjang periode pengamatan.

\section{DAFTAR PUSTAKA}

Alfredo, M. 2011. Pengaruh Kinerja Keuangan Teradap Nilai Perusahaan (Kebijakan Dividen Sebagai Variabel Moderating) Pada Perusahaan Manufaktur Di Bursa Efek Indonesia.Tesis.

Alfredo, M., Artini, L. G., \& Suarjaya, A. G. 2012. Pengaruh Kinerja Keuangan Terhadap Nilai Perusahaan Pada Perusahaan Manufaktur Di Bursa Efek Indonesia.Jurnal Manajemen, Strategi Bisnis, dan Kewirausahaan Vol. 6, No.2 , 130.

Anggraeni, M. D., \& Sulhan, M. 2020. Pengaruh Profitabilitas, Likuiditas dan Leverage Terhadap Nilai Perusahaan Dengan Kebijakan Dividen Sebagai Variabel Moderasi (Studi pada Perusahaan Manufaktur yang Terdaftar di BEI Tahun 2016-2018).Jurnal Ilmu Manajemen dan Akuntansi Terapan (JIMAT) Volume 11 Nomor 1, Mei , 2526-4440.

Atmaja, L. S. 2001. Manajemen Keuangan. Yogyakarta: ANDI.

Brigham, E. F., \& Houston, J. 2011. Dasar Dasar Manajemen Keuangan Buku Kedua Edisi Kesebelas. Jakarta: Salemba Empat.

Brigham, E. F., \& Houston, J. 2010. Dasar Dasar Manajemen Keuangan Edisi Kesebelas. Jakarta: Salemba Empat.

Brigham, E. F., \& Houston, J. F. 2012. Dasar Dasar Manajemen Keuangan Terjemahan Oleh Ali Akbar Yulianto.Buku kesatu. Edisi Kesebelas. Jakarta: Salemba Empat.

Brigham, E., \& Daves, P. 2014. Intermediate Financial Management Edisi 12. Singapore: Cengage Learning.

Brigham, E., \& Houston, J. 2006. Dasar-dasar Manajemen Keuangan, Edisi 10. Jakarta: Salemba Empat.

Bringham, E., \& Houston, J. 2001. Manajemen Keuangan (Edisi Kedelapan ed). Jakarta: Erlangga. Fahmi, I. 2014. Analisis Kinerja Keuangan. Bandung: Alfabeta.

Fahmi, I. 2015. Pengantar Manajemen Keuangan Teori dan Soal Jawab. Bandung: Alfabeta.

Fahmi, I. 2018. Pengantar Manajemen Keuangan Teori dan Soal Jawab. Bandung: ALFABETA, cv.

Fama, E. 1978. The Effects of a Firm's Investmen and Financing Decicions on the Welfare of Its Security Hoders. The American Economic Review, 272-284.

Firnanda, T., \& Oetomo, H. 2016. Analisis Likuiditas, Profitabilitas, Solvabilitas dan Perputaran Persediaan Terhadap Nilai Perusahaan.Jurnal Ilmu dan Riset Manajemen, Vol.5, No 2.

Ghozali, I. 2011. Aplikasi Analisis Multivariet Dengan Program SPSS. Semarang: Universitas Diponegoro.

Ghozali, I. 2012. Aplikasi Analisis Multivariate dengan Program IBM SPSS. Yogyakarta: Universitas Diponegoro.

Ghozali, I. 2013. Aplikasi Analisis Multivariate dengan Program IBM SPSS 21 Update PLS Regresi. Semarang: Badan Penerbit Universitas Diponegoro.

Gitman, L. 2003. Principles of Managerial Finance, 10th ed., International Editions Financial Series. Boston: Addison-Wesley.

Gitosudarmo, I., \& Basri. 2002. Manajemen Keuangan. Yogyakarta: BPFE.

Hanafi, M. M\& Halim, A. 2014. Analisis Laaporan Keuangan, Edisi Ketujuh, Cetakan Pertama. Yogyakarta: UPP AMP YKPN 
Harjito, Agus, \& Martono. 2011. Manajemen Keuangan Edisi Kedua. Yogyakarta: Cetakan Pertama.

Harmono. 2014. Manajemen Keuangan Berbasis Balanced Scored. Jakarta: PT Bumi Aksara. Husnan, S.2009.Dasar-dasar Teori Portofolio \& analisis sekuritas. Yogyakarta: UPP STIM YKPM.

Husnan, S, \& Pudjiastuti, E. 2006. Dasar-dasar manajemen keuangan. Yogyakarta: UPP STIM YKPM.

Ihsan, M., Munthe, I. L., \& Manik, T. 2018. Pengaruh Likuiditas, Leverage dan Profitabilitas Terhadap Nilai Perusahaan Dengan Kebijakan Dividen Sebagai Variabel Moderasi Pada Perusahaan Manufaktur Yang Listing di Bursa Efek Indonesia Tahun 2015 2017.Akuntansi, Fakultas Ekonomi, Universitas Maritim Raja Ali Haji .

Jariah, A. 2016. Likuiditas, Leverage, Profitabilitas Pengaruhnya Terhadap Nilai Perusahaan Manufaktur Di Indonesia Melalui Kebijakan Dividen.Riset Akuntansi dan Keuangan Indonesia.

Jogiyanto, H. 2013. Teori Portofolio dan Analisis Investasi. Yogyakarta: BPFE.

Kasmir. 2015. Analisis Laporan Keuangan, Edisi satu. Jakarta: PT Raja Grafindo Persada.

Lestari, Erna Yuliana. 2015. Pengaruh Leverage dan Profitabilitas Terhadap Nilai Perusahaan Dengan Kebijakan Dividen Sebagai Variabel Moderating.Naskah Publikasi.Jurusan Manajemen Fakultas Ekonomi dan Bisnis Muhammadiyah Yogyakarta.

Margaretha, F. 2014. Dasar-dasar Manajemen Keuangan. Jakarta: PT Dian Rakyat.

Mery, K. N. 2017. Pengaruh Likuiditas, Leverage dan Profitabilitas Terhadap Nilai Perusahaan Dengan Kebijakan Dividen Sebagai Variabel Moderasi Pada Perusahaan Pertambangan Yang Terdaftar Di Bursa Efek Indonesia Periode 2011-2014. JOM Fekon, Vol. 4 No. 1 Februari.

Mery, K., Zulbahridar, \& Kurnia, P. 2017. Pengaruh Likuiditas, Leverage dan Profitabilitas Terhadap Nilai Perusahaan dengan Kebijakan Dividen Sebagai Variabel Moderasi Pada Perusahaan Pertambangan yang Terdaftar di Bursa Efek Indonesia Tahun 2011-201.Jurnal Online Mahasiswa Fakultas Ekonomi Universitas Riau, 4(1), 2000-2014.

Nasser, Etty. 2008. Pengaruh Struktur Kepemilikan dan Dewan KomisarisIndependen Terhadap Nilai Perusahaan Dengan Manajemen Laba dan Kebijakan Hutang Sebagai Variabel Interveniing.Media Riset Akuntansi, Auditing dan Informasi. Volume 8. No 1. Hal 127.Jakarta.

Nisa, Ita K. 2017. Pengaruh Profitabilitas, Leverage, Kepemilikian Manajerial Terhadap Nilai Perusahaan Dengan Pengungkapan Corporate Sosial Responsibility(CSR) Sebagai Variabel Moderasi Pada Perusahaan Manufaktur Yang Terdaftar Di Bursa Efek Indonesia Periode 2012-2015.SKRIPSI.

Prasetya, A. W. 2020. Pengaruh Likuiditas, Profitabilitas dan Leverage Terhadap Nilai Perusahaan Yang Dimoderasi Oleh Kebijakan Dividen.Jurnal Ilmu Manajemen Volume 8 Nomor 4.

Prasetyorini, F. B. 2013. Pengaruh Ukuran Perusahaan, Leverage, Price Earning Ratio dan Profitabilitas Terhadap Nilai Perusahaan.Jurnal Ilmu Manajemen, Volume 1 No 1.

Putra, A. N., \& Lestari, P. V. 2016. Pengaruh Kebijakan Dividen, Likuiditas, Profitabilitas Dan Ukuran Perusahaan Terhadap Nilai Perusahaan.JurnalManajemen Unud, 4044 - 4070

Putri, R. W., \& Ukhriyawati, C. F. 2016.Pengaruh Likuiditas, Leverage dan Profitabilitas Terhadap Nilai Perusahaan Pada Perusahaan Telekomunikasi Yang Terdaftar dii Bursa Efek Indonesia Tahun 2012-2014.Jurnal Bening.

Rahmawati, U. N. 2017. Pengaruh Likuiditas, Leverage dan Profitabilitas Terhadap Nilai Perusahaan Dengan Kebijakan Dividen Sebagai Variabell Moderasi (Studi Pada Perusahaan Manufaktur Yang Terdaftar Dibursa Efek Indonesia. SKRIPSI.

Sartono, A. 2010. Manajemen Keuangan Teori dan Aplikasi. Yogyakarta: BPFE-YOGYAKARTA. 
Satrianto, A. 2020. Moderated Regression Analysis (MRA) Pelatihan Pengolahan Data. Fakultas Ekonomi Universitas Negeri Padang. Padang

Sembiring, R. 2003. Analisis Regresi Edisi Kedua. Bandung: ITB Bandung.

Sisca. 2016. Pengaruh Leverage dan Profitabilitas Terhadap Nila Perusahaan Dengan Kebijakan

Dividen Sebagai Variabel Moderasi Pada Perusahaan Manufaktur Yang Terdaftar di Bursa

Efek Indonesia Tahun 2010-2014.Jurnal SULTANIST, vol 4.no 1.

Sudana, I. M. 2011. Manajem Keuangan Perusahaan Teori \& Aplikasi. Jakarta: Erlangga.

Sudana, I. M. 2015. Manajem Keuangan Teori dan Praktek. Jakarta: Erlangga

Sugiyono. 2012. Metode Penelitian Bisnis. Bandung: Alfabeta.

Sugiyono. 2016. Metode penelitian kuantitatif, Kualitatif dan R\&D. Bandung: ALFABETA, cv.

Sugiyono. 2014.Metode Penelitian Kualitatif, Kuantitatif dan R\&D. Bandung: Alfabeta

Sugiyono. 2018. Metode Penelitian Kuantitatif. Bandung: Alfabeta

Suwardika, I., \& Mustanda, I. 2017. Pengaruh Leverage, Ukuran Perusahaan, Pertumbuhan Perusahaan dan Profitabilitas Terhadap Nilai Perusahaan Pada Perusahaan Properti.E-jurnal Manajemen Unud. Vol 6. No. 3, 1248-1277.

Syahyunan. 2013. Manajemen Keuangan: Perencanaan, Analisis, dan Pengendalian Keuangan.Medan:USU Press

Tandelilin, E. 2010. Portofolio dan Investasi Teori dan Aplikasi, Edisi Pertama. Yogyakarta: KANISIUS.

Tambun, S. 2013. Teknik Pengolahan Data dan Interpretasi Hasil Penelitian dengan Menggunakan Program SPSS Untuk Variabel Moderating.Workshop Metode Penelitian Kuantitatif.

Weston, J. F., \& Copeland, T. E. 2001. Manajemen Keuangan. Jakarta: Binarupa Aksara. www.idx.co.id

www.sahamoke.com 